\title{
投球ロボットのボール遠投性能を向上させる運動と身体の統合設計
}

\author{
宮菩 哲郎 ${ }^{* 1}$ ，兼清 暁大*2，土山 豊*3，眞田 一志*1
}

\section{Integrated design of body and motion improving motion performance of ball throwing robot}

\author{
Tetsuro MIYAZAKI ${ }^{* 1}$, Akihiro KANEKIYO*2 ${ }^{*}$, Yutaka TSUCHIYAMA ${ }^{* 3}$ and Kazushi SANADA ${ }^{* 1}$ \\ ${ }^{* 1}$ Faculty of Engineering, Yokohama National University \\ 79-5 Tokiwadai, Hodogaya-ku, Yokohama-shi, Kanagawa 240-8501, Japan \\ ${ }^{* 2}$ Graduate School of Engineering, Yokohama National University \\ 79-5 Tokiwadai, Hodogaya-ku, Yokohama-shi, Kanagawa 240-8501, Japan \\ ${ }^{* 3}$ School of Engineering, Yokohama National University \\ 79-5 Tokiwadai, Hodogaya-ku, Yokohama-shi, Kanagawa 240-8501, Japan
}

Received 22 June 2015

\begin{abstract}
This paper proposes an integrated robot design method which designs a robot body and a robot motion simultaneously to maximize the robot motion performance. The integrated robot design method is available to design a multi degrees of freedom (DOFs) robot, and it is validated by experiments of a ball throwing robot which has 9 DOFs. The design parameters are the motion pattern and the robot body parameters, and these initial values are optimized by a gradient method to maximize (or minimize) evaluation functions which are given from throwing task conditions. The throwing task conditions contain (i) maximization of ball flying distance, (ii) collision avoidance between flying ball and robot hand, (iii) velocity evaluation of motion, (iv) self collision avoidance and (v) limitations of joint angle, angular velocity and torque, etc.. These conditions are utilized as the constraints to obtain the realizable robot motion. A ball throwing motion performed by a human is transformed to a motion pattern of the ball throwing robot, and the robot body parameters are designed simultaneously. Two cases, which contain the improved motion 1 (the robot motion pattern is only designed) and improved motion 2 (the robot motion pattern and the robot body parameters are designed simultaneously), are compared, and these average ball flying distances are $1.33 \mathrm{~m}$ and $1.87 \mathrm{~m}$. As a result, the robot motion performance is improved, and effectiveness of the integrated robot design method is demonstrated.
\end{abstract}

Key words : Integrated robot design, Body design, Motion design, Ball throwing robot, Human motion

1.は じめ に

ロボットに目的のタスクを実行させるためには，まず目的のタスクを設定し，次にそのタスクを実行するための 身体と運動を設計するのが一般的である，とくに，ロボットの身体はタスクごとにその実行に適した身体構造や 形態が異なり，例えば産業用ロボットは限定されたタスクを効率よく反復的に実行するために目的のタスクの達 成に特化した身体をもち，ヒューマノイドロボットは人間に可能なタスクを汎用的に実行するために人間に似た 構造の身体をもつ。一般にロボット身体の設計作業では, 設計者が幾何学的・力学的特性やアクチュエータの性

\footnotetext{
No.15-00342 [DOI:10.1299/transjsme.15-00342], J-STAGE Advance Publication date : 4 December, 2015

*1 正員, 横浜国立大学大学院工学研究院（†240-8501 神奈川県横浜市保土ケ谷区常盤台 79-5)

*2 横浜国立大学大学院工学府

*3 横浜国立大学工学部

E-mail of corresponding author: t-miyazaki@ynu.ac.jp
} 
Miyazaki, Kanekiyo, Tsuchiyama and Sanada, Transactions of the JSME (in Japanese), Vol.82, No.833 (2016)

能などのさまざまな要素を考慮しながら構成部品を設計・選定して身体を組み上げ, その後動力学シミュレーショ ンなどによりロボット身体の運動を設計してタスクパフォーマンスを評価することで, 目的のタスク実行に適した 身体を設計する．ただし，ロボットのタスクのパフォーマンスは運動と身体の二要素によって決まるため，上記 のように運動と身体を別工程で設計する場合，先に設計した一方が後に設計するもう一方を制約することになり， その結果タスクのパフォーマンスが制約されることも考えられる.これに対し，上記の産業用ロボットのようにタ スクが限定的である場合，目的のタスクのパフォーマンスを高めるためには，一つの計算アルゴリズムの枠組み の中で運動と身体を統合的に最適化設計することが有効であろう. Endo ら (2003a, 2003b) は遺伝的アルゴリズム を用いた強化学習により歩行ロボットのリンク長と歩行運動パターンを設計した。歩行運動をシミュレーション 上で生成し，身体を運動とともに設計することで歩行距離が伸び，上半身の安定性が改善されることを示した。

本論文ではロボットの運動と身体を統合的に設計する事例として, 9 自由度空間マニピュレータである投球口 ボットの投球タスクと，これに適したロボットの身体を統合的に設計する事例について報告する．投球タスクは 人間が行う巧みな運動の代表格であり, ロボットの投球タスクを扱ったさまざまな従来研究が存在する. Braun ら (2013) は可変剛性関節を有するマニピュレータの投球運動を, 関節可動域などのアクチュエータの拘束を満たし つつ設計した. Kawai ら (2012) はヒューマノイドのフリースローを, 全モータの動作を同期させて設計する初期 習熟過程と, 各モータの動作を個別に設計する高度習熟過程に分けて効率的に設計した. 岡田ら (2014) は投擲口 ボットの初期姿勢の誤差が，投げられた物体の着地点に与える誤差の感度を解析し，着地点のばらつきが小さくな るように投擲運動を設計した。これらの研究では計算アルゴリズムの中でロボットの身体は設計せず，与えた身体 の投球タスクを扱っている．また，ロボットが多自由度・多リンク系である場合，タスクの条件を満たすように全 身運動を設計する問題は，一般に複雑な非線形性を有する幾何学的・力学的拘束下での軌道計画問題となる.これ に取り組むための計算アルゴリズムが従来研究で提案されてきている. 人間の運動パターンをヒューマンフィギュ アの運動 (Yamane and Nakamura, 2003) やヒューマノイドロボットの運動 (Yamane and Hodgins, 2009) に変換する 方法が提案された。中岡ら (2006) は人間の舞踊をロボットの運動に変換し, 上半身は舞踊動作の模倣, 下半身は 全身の運動を安定化しつつステップを行わせた。 また，キーポーズの姿勢とそれを補完したヒューマノイドロボッ トの運動の軌道を，腰部の水平位置を修正してバランスのとれたものに補正した (Nakaoka et al., 2010). Kanoun ら (2009) は運動の制約条件を順位付けし, 高順位の条件から優先的に満たすように運動を設計した. Suleiman ら (2008) は運動の軌道をスプライン関数で表し, そのパラメータを最適化することで角度・角速度・角加速度の微 分関係を容易に表した。亘島ら (2013) は心肺停止者のための胸骨圧迫を長時間楽に行うために，トルク総和が最 小となるように人間の身体に合わせて運動を最適化した. 宮菩ら (2014) は角加速度の時系列データを設計変数と し, 角加速度が微分不可能となることを許容しつつ 2 階微分可能な角度の軌道を設計する方法を提案した。これ らの方法は運動を行うものの身体に合わせて運動を変換するものであり, 身体の設計は行わない.

本論文で提案する方法は, 文献 (宮菩, 岡田, 2014) の計算アルゴリズムを用いて運動の時系列データを設計しつ つ, この枠組みの中で身体の設計変数も同時に設計するように拡張したものである. 身体の設計を追加するため には，身体パラメータを運動の時系列データと同様に設計変数として扱い，これを計算アルゴリズムの中で更新 可能とする必要がある，ただし，多リンク系の場合身体パラメータは多く存在し，これらすべてを独立変数とし て扱うと探索次元が多くなり，計算の収束性の悪化や，計算時間の増大が予想される，そこで，提案方法では身体 パラメータ間に存在する幾何学的・力学的な依存関係を利用し, 身体パラメータの設計空間を低次元化する. 具 体的には, 計算アルゴリズムの中でリンク長のみを身体の設計変数とし, リンク質量, 重心位置, 慣性テンソル を計算アルゴリズムの中で自動的に算出するようにした。ここでは, 運動の時系列データの初期值として, モー ションキャプチャで計測した人間の投球運動の時系列データを与え, 身体の設計変数の初期值として投球ロボット の腕部リンク長を与える. そして, 投球タスクの条件として, (i) ボール飛距離の最大化, (ii) 投球後のボールと手 の非接触条件, (iii) 運動開始・終了時の速度評価, (iv) 自己衝突回避の条件, (v) 角度・角速度・トルクの制限を与 え，これを満たすように投球ロボットの運動と身体を設計する. 設計変数の計算アルゴリズムには最急降下法を 用い, 投球タスクの条件下での運動と身体の局所的な最適解を導出する. 実験検証では, 運動のみを設計した結 果と, 運動と身体を統合的に設計した結果とを比較し, 後者の方がロボットが投げたボールの飛距離が向上する ことを示す.

本論文の構成は，2 章で制御対象である投球ロボットと，その運動と身体の統合設計法について述べ，3章で提 


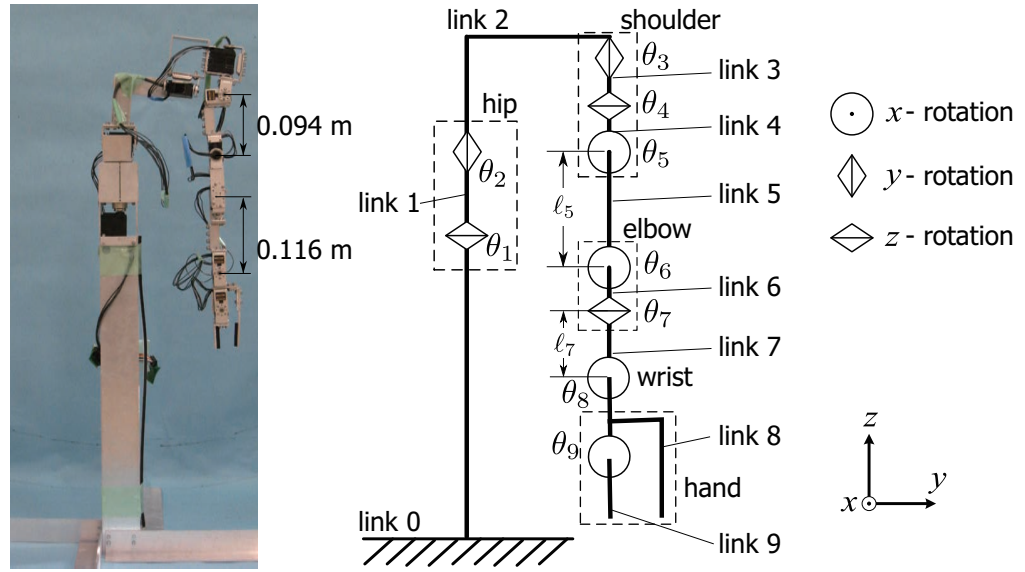

Fig. 19 DOFs ball throwing robot and its link model.

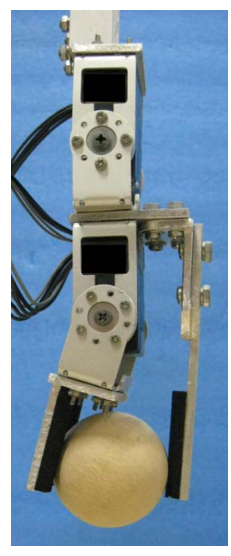

Fig. 2 Robot hand which is holding ball.

案方法により設計した運動と身体の計算結果を示し，4 章で実験結果を示し，最後に 5 章で本論文で得られた知見 についてまとめる.

\section{2. 投球ロボットの運動と身体の統合設計}

\section{$2 \cdot 1$ 投球ロボット}

投球運動を行わせるロボットの実機とそのリンクモデルを図 1 に示す。ロボットはリンク 8 とリンク 9 で構成 される手を開閉させてボールを図 2 のように把持・開放し，投球を行う．このロボットの図 1 の姿勢での床から の全高は $0.84 \mathrm{~m}$, 静止リンク 0 を除く可動部の全質量は $1.2 \mathrm{~kg}$ である. リンク系は腰に 2 自由度 $\left(\theta_{1}, \theta_{2}\right)$, 肩に 3 自由度 $\left(\theta_{3}, \theta_{4}, \theta_{5}\right)$, 肘に 2 自由度 $\left(\theta_{6}, \theta_{7}\right)$, 手首 $\left(\theta_{8}\right)$ と手 $\left(\theta_{9}\right)$ に 1 自由度ずつ関節を持つ合計 9 自由度の 10 リンク系であり, 関節はすべて DC サーボモータで駆動される能動関節である. ロボットの関節は, 人間が上 半身のみを動かして行う投球運動を参考に, この運動を模擬して配置した．全ての関節で共通のサーボモータを

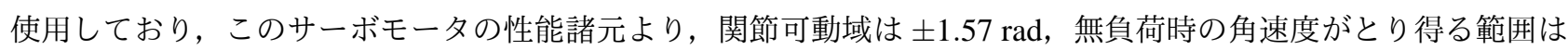
$\pm 7.48 \mathrm{rad} / \mathrm{s}$, トルクの範囲は $\pm 4.02 \mathrm{Nm}$, 駆動電圧の範囲は $\pm 18 \mathrm{~V}$ である. 本論文では図 1 のロボット実機を初 期身体と呼ぶこととする．初期身体は著者らが直観的に設計したものであり，この方法ではボールの飛距離が最 大となる身体を設計するのは難しく, 初期身体には改良の余地があると思われる. 本論文の提案する計算アルゴ リズムではロボットの身体パラメータを運動と身体の統合設計における設計変数とし, ボールの飛距離が向上す るようにロボットの身体形状を変化させる.

\section{$2 \cdot 2$ 問題の設定と設計変数について}

関節 $i(=1, \cdots, 9)$ の相対角を $\theta_{i}[\mathrm{rad}]$, 関節 $i$ を駆動するトルクを $\tau_{i}[\mathrm{Nm}]$ とする. 次に, 時間ステップ $k(=1, \cdots, n)$ での各関節の相対角とトルクをそれぞれまとめたベクトル $\boldsymbol{\theta}_{[k]}$ と $\boldsymbol{\tau}_{[k]}$ を

$$
\boldsymbol{\theta}_{[k]}=\left[\begin{array}{lll}
\theta_{1[k]} & \cdots & \theta_{9[k]}
\end{array}\right]^{T}, \boldsymbol{\tau}_{[k]}=\left[\begin{array}{lll}
\tau_{1[k]} & \cdots & \tau_{9[k]}
\end{array}\right]^{T}
$$

とする.さらに, $\boldsymbol{\theta}_{[k]}$ と $\boldsymbol{\tau}_{[k]}$ を一連の運動の全時間ステップでそれぞれまとめた行列 $\boldsymbol{\Theta} と \boldsymbol{T}$ を

$$
\boldsymbol{\Theta}=\left[\begin{array}{lll}
\boldsymbol{\theta}_{[1]} & \cdots & \boldsymbol{\theta}_{[n]}
\end{array}\right], \boldsymbol{T}=\left[\begin{array}{lll}
\boldsymbol{\tau}_{[1]} & \cdots & \boldsymbol{\tau}_{[n]}
\end{array}\right]
$$

とする. 本研究で提案する計算アルゴリズムの最終的な目標は, 投球ロボットの実現可能な運動パターンとして

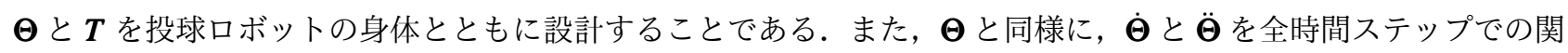
節角速度ベクトル $\dot{\boldsymbol{\theta}}_{[k]}$ と角加速度ベクトル $\ddot{\boldsymbol{\theta}}_{[k]}$ をそれぞれまとめた行列とする. 本論文では, 運動と身体の設計 変数は

$$
\boldsymbol{\theta}_{[1]}, \dot{\boldsymbol{\theta}}_{[1]}, \ddot{\boldsymbol{\Theta}}, \Delta t, \ell_{5}, \ell_{7}
$$


とする.ただし， $\Delta t[\mathrm{~s}]$ はサンプリングタイム， $\ell_{5}$ と $\ell_{7}[\mathrm{~m}]$ は図 1 に示すように投球ロボットの上腕と前腕の長手 方向のリンク長を表す. 式 (3) 中, $\boldsymbol{\theta}_{[1]}, \dot{\boldsymbol{\theta}}_{[1]}, \ddot{\Theta}, \Delta t$ は運動の設計変数であり, $\ell_{5}$ と $\ell_{7}$ は身体の設計変数である. ここで， $\ell_{5}$ と $\ell_{7}$ のみを身体の設計変数とする理由を述べる. 投球ロボットの身体パラメータは多く, このうちリ ンク長のみを設計変数としても, 10 リンク系のリンク長 $x y z$ 成分のパラメータは合計 30 個あり, すべてのリンク 長を設計するのは計算負荷が大きい，そこで，本論文ではリンク長パラメータの中からロボットの投球タスクに 比較的大きな影響を与えると思われる $\ell_{5}$ と $\ell_{7}$ の二つを身体の設計変数として選択し，これらのみを設計する．た だし，この選択は著者らの直観的な判断に基づくものであり，身体の設計変数がこの二つで十分である保証はな く, 今後改善の余地がある. $\ell_{5}$ と $\ell_{7}$ とともに変化するリンク 5 あるいはリンク 7 のリンク長以外の身体パラメー タは $\ell_{5}$ と $\ell_{7}$ の関数として表すが, これについては $2 \cdot 3$ 章で詳述する.

本論文では, 運動の設計変数 $\boldsymbol{\theta}_{[1]}, \dot{\boldsymbol{\theta}}_{[1]}, \ddot{\Theta}, \Delta t$ の初期值としてモーションキャプチャで計測した人間の投球運 動の角度データと，これを時間差分した角速度・角加速度データおよび差分に用いたサンプリングタイムを与え る. 身体の設計変数初期值は 2.1 章の通り初期身体のものを与える. $\Delta t$ を設計変数に含めた意図は, 一連の運動 に要する時間が人間とロボットで異なる場合に対応するためである. 実際, 人間とロボットでは身体のスケール が大きく異なり，運動に要する時間も異なると考えるのが自然である.

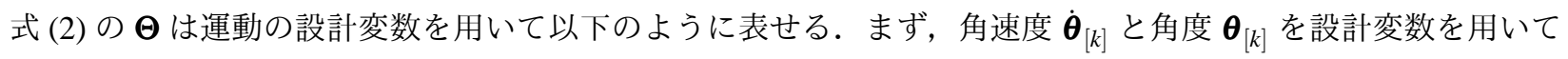

$$
\dot{\boldsymbol{\theta}}_{[k]}=\dot{\boldsymbol{\theta}}_{[1]}+\Delta t \sum_{\alpha=1}^{k-1} \ddot{\boldsymbol{\theta}}_{[\alpha]}, \quad \boldsymbol{\theta}_{[k]}=\boldsymbol{\theta}_{[1]}+\Delta t \sum_{\alpha=1}^{k-1} \dot{\boldsymbol{\theta}}_{[\alpha]}
$$

のようにオイラー近似を用いた数值積分で与える.式 (4)を一連の運動のデータ $\dot{\Theta ， \Theta に ま と め る と ~}$

$$
\begin{aligned}
& \dot{\boldsymbol{\Theta}}=\dot{\boldsymbol{\theta}}_{[1]} \boldsymbol{F}_{1}+\ddot{\boldsymbol{\Theta}} \boldsymbol{F}_{2} \\
& \boldsymbol{\Theta}=\boldsymbol{\theta}_{[1]} \boldsymbol{F}_{1}+\dot{\boldsymbol{\theta}}_{[1]} \boldsymbol{F}_{1} \boldsymbol{F}_{2}+\ddot{\boldsymbol{\Theta}} \boldsymbol{F}_{2}^{2} \\
& \boldsymbol{F}_{1}=\left[\begin{array}{lll}
1 & \cdots & 1
\end{array}\right], \boldsymbol{F}_{2}=\left[\begin{array}{cccc}
0 & \Delta t & \cdots & \Delta t \\
\vdots & \ddots & \ddots & \vdots \\
\vdots & & \ddots & \Delta t \\
0 & \cdots & \cdots & 0
\end{array}\right]
\end{aligned}
$$

となる. ただし, $\boldsymbol{F}_{1} \in \boldsymbol{R}^{1 \times n}, \boldsymbol{F}_{2} \in \boldsymbol{R}^{n \times n}$ である. また，投球ロボットはホロノミック系であるため, トルク $\boldsymbol{\tau}_{[k]}$ は ロボットモデルの逆動力学解析より

$$
\boldsymbol{\tau}_{[k]}=\boldsymbol{\tau}\left(\boldsymbol{\theta}_{[k]}, \dot{\boldsymbol{\theta}}_{[k]}, \ddot{\boldsymbol{\theta}}_{[k]}, \ell_{5}, \ell_{7}\right)=\boldsymbol{\tau}\left(\boldsymbol{\theta}_{[1]}, \dot{\boldsymbol{\theta}}_{[1]}, \ddot{\boldsymbol{\Theta}}, \Delta t, \ell_{5}, \ell_{7}\right)
$$

のように表せ，これより一連のトルクデータ $\boldsymbol{T}$ を得る.

\section{$2 \cdot 3$ 身体パラメータ間の依存関係}

ロボット身体のパラメータすべてを独立変数として扱うと探索次元が多くなるが，身体パラメータ間には互い に幾何学的・力学的な依存関係があるため, 提案方法ではこれを利用して身体パラメータの設計空間を低次元化 する.これにより, 計算アルゴリズムの中で投球タスクに適したリンク長, リンク質量, 重心位置, 慣性テンソル が設計される. 本論文では, リンク 5 とリンク 7 のリンク長 $\ell_{5}$ と $\ell_{7}$ を設計変数とし, リンク 5 とリンク 7 のその 他のパラメータであるリンク質量, 重心位置, 慣性テンソルをリンク長の関数として表し, 計算アルゴリズムの 中でこれらを計算する．ここではリンク 5 のパラメータをリンク長 $\ell_{5}$ の関数として表すことについて述べる.ま ず，図 3 のようにリンク 5 を肩部，腕部，ひじ部に三分割する. 肩部とひじ部はモータを含む複数の部品で構成 され，腕部はアルミチャンネル材を加工した単一部品である.リンク長 $\ell_{5}$ は関節 5 と関節 6 の回転中心間の $z$ 軸 方向の距離であり，身体の設計では腕部長さを変化させることで $\ell_{5}$ を変化させる. 図中, $m_{5}, \boldsymbol{p}_{85}, \boldsymbol{I}_{5}$ はそれぞ れリンク 5 全体の質量, 重心位置ベクトル, 重心周りの慣性テンソルである. また, 添え字 $s, a, e$ はそれぞれ肩 部, 腕部, ひじ部のパラメータであることを表す. 図 3 中, 破線で囲まれたパラメータは $\ell_{5}$ の関数として表され, 


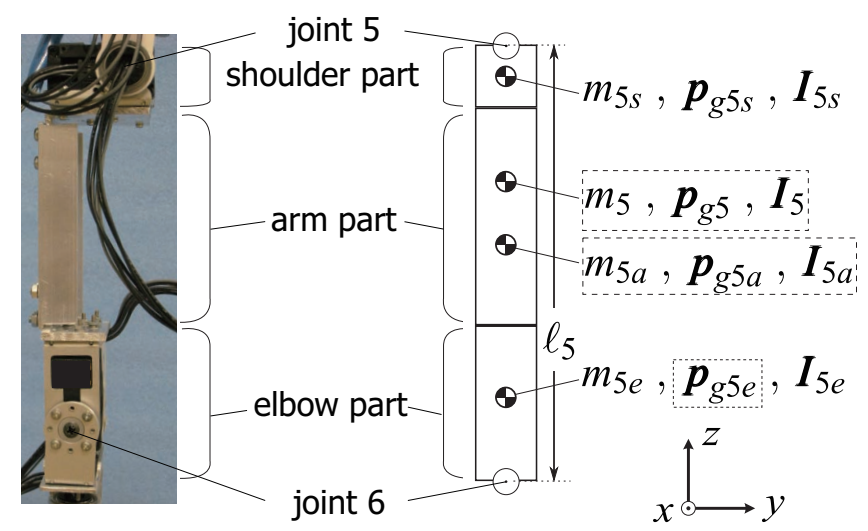

Fig. 3 Link 5 divided into 3 parts.

腕部とひじ部については

$$
\begin{aligned}
& m_{5 a}\left(\ell_{5}\right)=m_{5 a}\left(\ell_{50}\right)+\rho_{5 a}\left(\ell_{5}-\ell_{50}\right) \\
& \boldsymbol{p}_{55 a}\left(\ell_{5}\right)=\boldsymbol{p}_{55 a}\left(\ell_{50}\right)-\left[\begin{array}{lll}
0 & 0 & \left(\ell_{5}-\ell_{50}\right) / 2
\end{array}\right]^{T} \\
& \boldsymbol{p}_{95 e}\left(\ell_{5}\right)=\boldsymbol{p}_{95 e}\left(\ell_{50}\right)-\left[\begin{array}{lll}
0 & 0 & \left(\ell_{5}-\ell_{50}\right)
\end{array}\right]^{T} \\
& \boldsymbol{I}_{5 a}\left(\ell_{5}\right)=\left[\begin{array}{ccc}
I_{5 a x x}\left(\ell_{5}\right) & 0 & 0 \\
0 & I_{5 a y y}\left(\ell_{5}\right) & 0 \\
0 & 0 & I_{5 a z z}\left(\ell_{5}\right)
\end{array}\right] \\
& I_{5 a x x}\left(\ell_{5}\right)=I_{5 a y y}\left(\ell_{5}\right)=m_{5 a}\left(\ell_{5}\right)\left\{\ell_{5 a 0}+\left(\ell_{5}-\ell_{50}\right)\right\}^{2} / 12 \\
& I_{5 a z z}\left(\ell_{5}\right)=I_{5 a z z}\left(\ell_{50}\right) m_{5 a}\left(\ell_{5}\right) / m_{5 a}\left(\ell_{50}\right)
\end{aligned}
$$

となる.ただし， $\ell_{50}[\mathrm{~m}]$ は $\ell_{5}$ の初期値であり， $\rho_{5 a}[\mathrm{~kg} / \mathrm{m}]$ は腕部の単位長さあたりの質量である. $\boldsymbol{I}_{5 a}$ の慣性乗積 は対角成分に対し十分小さいため 0 に近似した。各部のパラメータを用いて，リンク 5 全体のパラメータは

$$
\begin{aligned}
& m_{5}\left(\ell_{5}\right)=m_{5 s}+m_{5 a}\left(\ell_{5}\right)+m_{5 e} \\
& \boldsymbol{p}_{95}\left(\ell_{5}\right)=\frac{m_{5 s} \boldsymbol{p}_{95}+m_{5 a}\left(\ell_{5}\right) \boldsymbol{p}_{g 5 a}\left(\ell_{5}\right)+m_{5 e} \boldsymbol{p}_{g 5 e}\left(\ell_{5}\right)}{m_{5}\left(\ell_{5}\right)} \\
& \boldsymbol{I}_{5}\left(\ell_{5}\right)=\boldsymbol{I}_{5 s g}\left(\ell_{5}\right)+\boldsymbol{I}_{5 a g}\left(\ell_{5}\right)+\boldsymbol{I}_{5 e g}\left(\ell_{5}\right) \\
& \boldsymbol{I}_{5 s g}\left(\ell_{5}\right)=\boldsymbol{I}_{5 s}+m_{5 s} \boldsymbol{\gamma}\left(\boldsymbol{p}_{55 s}-\boldsymbol{p}_{g 5}\left(\ell_{5}\right)\right) \\
& \boldsymbol{I}_{5 a g}\left(\ell_{5}\right)=\boldsymbol{I}_{5 a}\left(\ell_{5}\right)+m_{5 a}\left(\ell_{5}\right) \boldsymbol{\gamma}\left(\boldsymbol{p}_{g 5 a}\left(\ell_{5}\right)-\boldsymbol{p}_{g 5}\left(\ell_{5}\right)\right) \\
& \boldsymbol{I}_{5 e g}\left(\ell_{5}\right)=\boldsymbol{I}_{5 e}+m_{5 e} \boldsymbol{\gamma}\left(\boldsymbol{p}_{95 e}\left(\ell_{5}\right)-\boldsymbol{p}_{g 5}\left(\ell_{5}\right)\right)
\end{aligned}
$$

のように表せる.ただし， $\boldsymbol{I}_{5 s g}, \boldsymbol{I}_{5 a g}, \boldsymbol{I}_{5 e g}$ はそれぞれリンク 5 全体の重心周りの各部の慣性テンソルであり， $\boldsymbol{\gamma}$ は

$$
\begin{aligned}
& \boldsymbol{\gamma}(\boldsymbol{p})=\left[\begin{array}{ccc}
p_{y}^{2}+p_{z}^{2} & p_{x} p_{y} & p_{x} p_{z} \\
p_{x} p_{y} & p_{x}^{2}+p_{z}^{2} & p_{y} p_{z} \\
p_{x} p_{z} & p_{y} p_{z} & p_{x}^{2}+p_{y}^{2}
\end{array}\right] \\
& \boldsymbol{p}=\left[\begin{array}{lll}
p_{x} & p_{y} & p_{z}
\end{array}\right]^{T}
\end{aligned}
$$

という関数である.リンク 5 と同様に, リンク 7 のパラメータも $\ell_{7}$ の関数として表す.

\section{4 ボール飛距離の最大化}

本論文での目的のタスクは投球タスクであり, ここではボールの飛距離を評価関数とし, 飛距離が長いほど投 球ロボットのパフォーマンスは高いものとする. 図 4 に投げられたボールが描く軌道の様子を示す. 静止座標系 


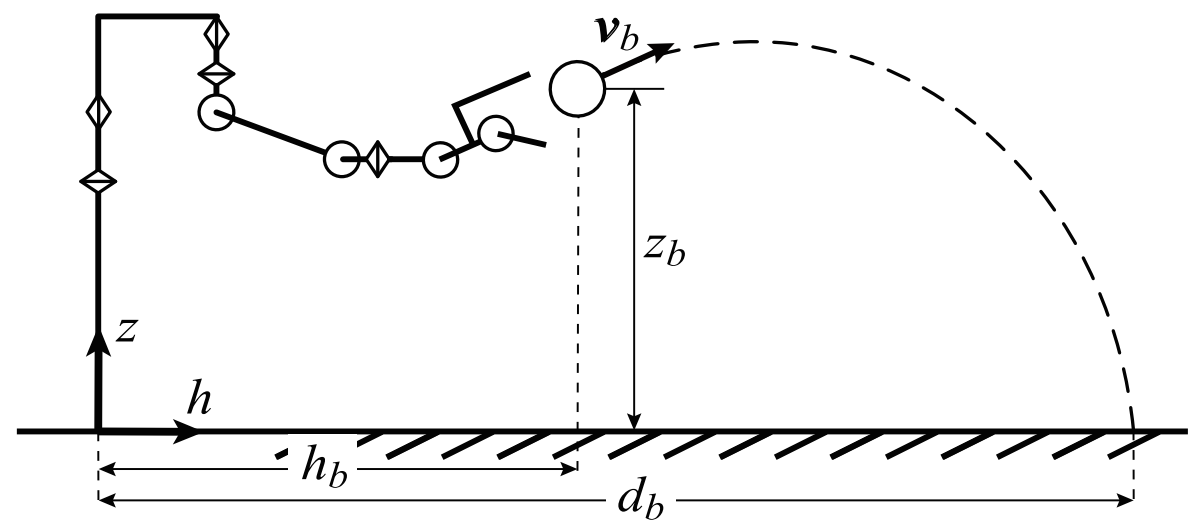

Fig. 4 Thrown ball trajectory.

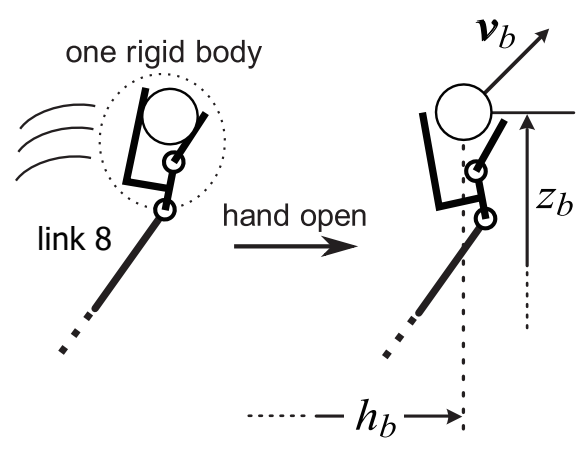

Fig. 5 Moment of hand opening.

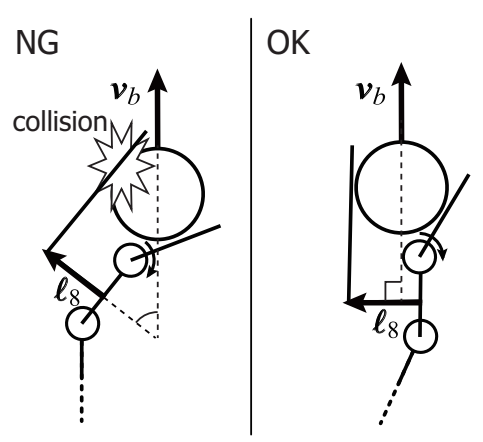

Fig. 6 Throwing direction and hand direction.

$h-z$ を図のように設定し，座標軸 $h$ はボールが飛んでいく方向である. 手とボールが離れる瞬間のボールの速度 $\boldsymbol{v}_{b}=\left[\begin{array}{ll}v_{b h} & v_{b z}\end{array}\right]^{T}[\mathrm{~m} / \mathrm{s}]$ と位置 $h_{b}, z_{b}[\mathrm{~m}]$ を与えるとボールの飛距離 $d_{b}[\mathrm{~m}]$ が

$$
d_{b}=\frac{1}{g}\left(v_{b z}+\sqrt{v_{b z}^{2}+2 g z_{b}}\right) v_{b h}+h_{b}
$$

のように決まる.ただし, $g\left[\mathrm{~m} / \mathrm{s}^{2}\right]$ は重力加速度であり, 空中のボールに加わる外力はなく, 空気抵抗を無視でき ると仮定した。ボールの初期条件 $v_{b}, h_{b}, z_{b}$ はロボットの運動と身体から与えられるものであり， $d_{b}$ はボールを 投げる瞬間のロボットの関節角度と角速度およびリンク長の関数として表すことができる. ボールの飛距離 $d_{b}$ を 最大化するようにロボットの運動と身体を設計する.

ここで，投球の瞬間におけるロボットの手とボールの接触状態について述べる．本論文では，図 5 のうにロ ボットがボールを把持している間は手（リンク 8）とボールを一つの剛体として扱い，手を開いてボールの固定を 解く瞬間に手とボールが離れ，接触力が 0 になると仮定する。これに対し，人間の投球では把持を解いた瞬間に接 触力が 0 にはならず，解放後さらに指先がボールを押して加速するという違いがあるが，本論文では投球運動を 簡単なモデルで表すために上記のような仮定を与えた。ボールの固定を解く瞬間のリンク 8 の運動の状態がボー ルの初期速度 $\boldsymbol{v}_{b}$ と位置 $h_{b}, z_{b}$ を決定する。運動開始から終了までの時間ステップ $k=1, \cdots, n$ のうち，手を開く 瞬間をステップ $k_{o}\left(1 \leq k_{o} \leq n\right)$ とし，このときの飛距離 $d_{b\left[k_{o}\right]}$ を最大化するアルゴリズム

$$
\begin{aligned}
& \max _{\boldsymbol{\theta}_{[1]} \dot{\boldsymbol{\theta}}_{[1]} \ddot{\boldsymbol{\Theta}} \Delta t \ell_{5} \ell_{7}} d_{b}\left[k_{o}\right] \\
& d_{b\left[k_{o}\right]}=d_{b}\left(\boldsymbol{\theta}_{\left[k_{o}\right]}, \dot{\boldsymbol{\theta}}_{\left[k_{o}\right]}, \ell_{5}, \ell_{7}\right)=d_{b}\left(\boldsymbol{\theta}_{[1]}, \dot{\boldsymbol{\theta}}_{[1]}, \ddot{\boldsymbol{\Theta}}, \Delta t, \ell_{5}, \ell_{7}\right)
\end{aligned}
$$

を用いて設計変数を求める. ステップ $k_{o}$ の決定には，運動の設計変数の初期值である人間の運動パターンを用い る.人間の運動パターンの全時間ステップでボール飛距離 $d_{b[k]}(k=1, \cdots, n)$ を計算し，この中で飛距離が最大と なる時間ステップを $k_{o}$ とする．計算アルゴリズムの中で投球の瞬間の時間ステップ $k_{o}$ を固定し，サンプリングタ イム $\Delta t$ を設計変数として変化させるため，運動開始から投球の瞬間までにかかる実際の時間（秒）は変化する. 
ただし，本来は計算アルゴリズムの中で $k_{o}$ も変化するのが自然だが，計算量や収束性などの理由から本論文では $k_{o}$ を先に決めて固定した. $k_{o}$ の設計変数化は今後の課題である.

\section{5 投球後のボールと手の非接触条件}

ボールの飛距離計算では，投げた後のボールには外力が加わらないという仮定を用いており，これを満たすた めにはボールの固定を解いた後にボールと手が衝突しないように運動を設計する必要がある．図 6 に，投球の瞬 間のボールの速度ベクトル $v_{b}$ と手の向きを表す単位ベクトル $\ell_{8}$ が直交しない場合と直交する場合を示す．図 6 左 は直交しない場合であり，このときボールが飛んでいく方向に手が覆いかぶさっているため，これらは衝突する可 能性が高い．図 6 右は直交する場合であり，手の開口部方向にボールが飛ぶため，ボールと手はぶつかりにくい と考えられる。これを投球後のボールと手の非接触条件とし，設計変数の計算アルゴリズムに実装する．条件は

$$
\boldsymbol{\ell}_{8}^{T} \boldsymbol{v}_{b}=0
$$

のように表され，式 (26)を満たすために，以下のアルゴリズム

$$
\begin{gathered}
\min _{\boldsymbol{\theta}_{[1]} \dot{\boldsymbol{\theta}}_{[1]} \ddot{\boldsymbol{\Theta}}_{\Delta t \ell_{5} \ell_{7}} E_{O}} \\
E_{o}=\frac{\left(\boldsymbol{\ell}_{8}^{T} \boldsymbol{v}_{b}\right)^{2}}{\left\|\boldsymbol{v}_{b}\right\|^{2}}
\end{gathered}
$$

を用いて， $E_{o}$ の最小化を最適化計算の条件に含めることとした.

\section{$2 \cdot 6$ 運動開始・終了時の速度評価}

投球実験を行うとき，ロボットは運動開始時（時間ステップ 1）と終了時（時間ステップ $n$ ）に十分低速である ことが安全上の観点から望ましい，理想的な状態は運動開始時と終了時にロボットが停止していることであり，そ の条件は

$$
\dot{\boldsymbol{\theta}}_{[1]}=\mathbf{0}, \dot{\boldsymbol{\theta}}_{[n]}=\mathbf{0}
$$

のように表され，設計する運動パターンの最初と最後の時間ステップでの角速度ベクトルを 0 とする．この条件 を以下のアルゴリズム

$$
\begin{aligned}
& \min _{\dot{\boldsymbol{\theta}}_{[1]} \ddot{\boldsymbol{\Theta}} \Delta t} E_{S} \\
& E_{S}=\left\|\dot{\boldsymbol{\theta}}_{[1]}\right\|^{2}+\left\|\dot{\boldsymbol{\theta}}_{[n]}\right\|^{2}
\end{aligned}
$$

を用いて， $E_{s}$ の最小化を最適化計算の条件に含めることとした。これにより，運動開始・終了時にロボットが十 分低速となるように運動を設計する. $\dot{\boldsymbol{\theta}}_{[1]}$ は設計変数だが，式 (29) を満たすために $\dot{\boldsymbol{\theta}}_{[1]}=\mathbf{0}$ で固定することも考 えられる.ただし, $\dot{\boldsymbol{\theta}}_{[1]}$ は他の投球タスクの条件にも関連するため, 本論文では $\dot{\boldsymbol{\theta}}_{[1]}$ を 0 に固定せず, 再帰計算ア ルゴリズムの中で 0 近傍に収束させる方法を採る.

\section{$2 \cdot 7$ 自己衝突回避の条件}

投球運動時のロボットは自己の身体を構成するリンク間で衝突が起こらないようにする必要があり，これを自 己衝突回避の条件として計算アルゴリズムに実装する，図 7 のように，胴体部・腰部リンクと関節 $6 ， 8$ の距離を 図中破線で表されているリンクからの最近傍距離 $d_{c}[\mathrm{~m}]$ 以上とすることで自己衝突を回避する. 図 8 を用いて，3 次元空間上の点と直線の最小距離について述べる. 図中, 直線は点 $\boldsymbol{p}_{1}$ を通り, ベクトルvに平行であるとき, こ の直線と点 $\boldsymbol{p}_{2}$ の最小距離 $d$ が

$$
\begin{aligned}
& d=\|\boldsymbol{d}\| \\
& \boldsymbol{d}=\boldsymbol{p}_{1}+\frac{\boldsymbol{v}}{\|\boldsymbol{v}\|^{2}}\left\{\boldsymbol{v} \cdot\left(\boldsymbol{p}_{2}-\boldsymbol{p}_{1}\right)\right\}-\boldsymbol{p}_{2}
\end{aligned}
$$




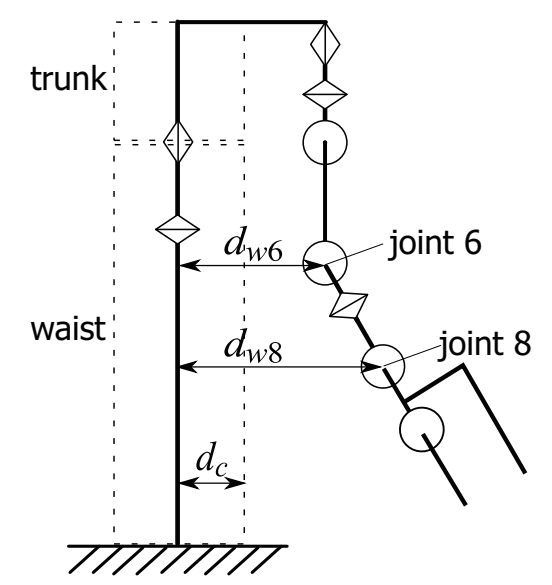

Fig. 7 Considered distances between joints and links to avoid self collision.

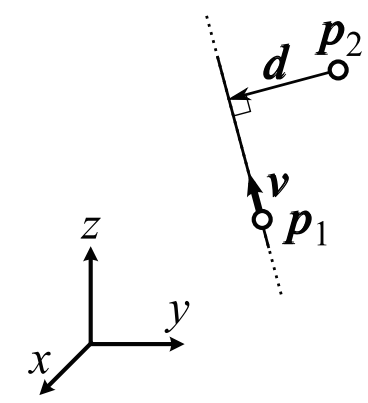

Fig. 8 Minimum distance between line and point.

のように決まる．式 (33) を用いて，投球ロボットのリンクと関節の最小距離を求める. 腰部リンクと関節 6,8 の 距離を $d_{w 6}, d_{w 8}$ とし, 胴体部リンクと関節 6,8 の距離を $d_{t 6}, d_{t 8}$ として, これらを設計変数で表し, 以下の条件

$$
d_{c} \leq d_{w 6[k]}, d_{w 8[k]}, d_{t 6[k]}, d_{t 8[k]}(k=1, \cdots, n)
$$

を満足するように設計変数を求める. ただし, ここで求めている距離は無限長の直線と点の距離であり, 実際の リンク長は有限なので, 式 (34) を満たさなくても衝突しない場合もある. 例えば, オーバースローの場合は腕を 肩より上に挙げている間は式 (34) を満たさなくても衝突しない. このため, 有限長のリンクと点の距離を条件と して与える方がより自然だが，この場合リンクと点の位置関係で距離の計算に場合分けが必要となる. 本論文で は，自己衝突回避の条件を簡単なものとして実装するために式 (34) で与えた. また，ここでは特定のリンクと関 節の距離を選択的に考慮したが，これはすべてのリンクや関節の衝突回避を考慮するのが難しいためであり，式 (34) を満たしても自己衝突が発生する可能性はある. 自己衝突が発生しないことの最終的な確認は, 設計した運 動パターンをスローモーションで実験機に実行させて行う，衝突が発生する場合は， $d_{c}$ をきくする，考慮する 距離を追加するなどの対策を行った。

\section{$2 \cdot 8$ 角度・角速度・トルクの制限}

設計する運動パターンはロボットの関節可動域とアクチュエータの角速度・トルクの制限を満たす必要がある. まず角度の制限は

$$
\theta_{i}^{\min } \leq \theta_{i[k]} \leq \theta_{i}^{\max } \quad(k=1, \cdots, n)
$$

のように与える.ただし， $\theta_{i[k]}$ は時間ステップ $k$ での関節 $i(=1, \cdots, 9)$ の角度であり, $\theta_{i}^{\min }$ と $\theta_{i}^{\max }$ は関節 $i$ の角 度の下限值と上限值である. $\theta_{i}^{\min }$ と $\theta_{i}^{\max }$ は 2.1 章で述べた投球ロボットの関節可動域 $( \pm 1.57 \mathrm{rad})$ 内の值を設定 する. 次に，角速度とトルクの制限を図 9 で表す. 投球ロボットに使用する DC サーボモータの特性により角速度 とトルクは制限され， $\tau-\dot{\theta}$ 空間において図 9 に示す斜線部の領域内がモータの実現可能な角速度とトルクを示し 


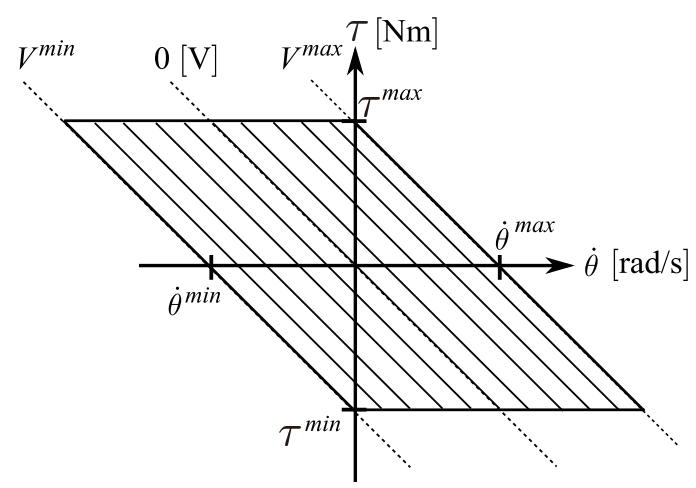

Fig. 9 Limitations of angular velocity and torque (dashed area is feasible to DC motor property).

ている. 図中， $\tau^{\min }$ と $\tau^{\max }$ はトルク下限值および上限值であり， $\dot{\theta}^{\min }$ と $\dot{\theta}^{\max }$ は無負荷時の角速度下限值および上 限值である。また， $V^{\min } と V^{\max }$ は印加電圧の下限值および上限值であり，これら制限值が領域の境界を与える. 制限值は $2 \cdot 1$ 章で述べた DC サーボモータ性能諸元を満たすように設定する. 図 9 中，第 $1 \cdot 3$ 象限はモータ駆動 領域, 第 $2 \cdot 4$ 象限はモータ発電領域であり, 象限ごとに異なる制限となっている. 各象限における時間ステップ $k$ での関節 $i$ の角速度・トルクの制限は

$$
\begin{array}{lc}
\dot{\theta}_{i}^{\text {max }} \tau_{i[k]}+\tau_{i}^{\text {max }} \dot{\theta}_{i[k]} \leq \dot{\theta}_{i}^{\text {max }} \tau_{i}^{\text {max }} & \left(\tau_{i[k]}>0 \text { かつ } \dot{\theta}_{i[k]}>0\right) \\
\tau_{i[k]} \leq \tau_{i}^{\text {max }} \text { かつ } \dot{\theta}_{i}^{\text {min }} \tau_{i[k]}+\tau_{i}^{\text {min }} \dot{\theta}_{i[k]} \leq \dot{\theta}_{i}^{\text {min }} \tau_{i}^{\text {min }} & \left(\tau_{i[k]}>0 \text { かつ } \dot{\theta}_{i[k]}<0\right) \\
\dot{\theta}_{i}^{\text {min }} \tau_{i[k]}+\tau_{i}^{\text {min }} \dot{\theta}_{i[k]} \leq \dot{\theta}_{i}^{\text {min }} \tau_{i}^{\text {min }} & \left(\tau_{i[k]}<0 \text { かつ } \dot{\theta}_{i[k]}<0\right) \\
\tau_{i}^{\text {min }} \leq \tau_{i[k]} \text { かつ } \dot{\theta}_{i}^{\text {max }} \tau_{i[k]}+\tau_{i}^{\text {max }} \dot{\theta}_{i[k]} \leq \dot{\theta}_{i}^{\text {max }} \tau_{i}^{\max } & \left(\tau_{i[k]}<0 \text { かつ } \dot{\theta}_{i[k]}>0\right)
\end{array}
$$

のように表せる. 式 $(35) \sim(39)$ で与えられる制限を満足するように設計変数を求める.

\section{9 設計変数の計算アルゴリズム}

与えた条件のもとで設計変数を求める計算アルゴリズムには最急降下法を用いる．再帰計算では計算一回ごと に $2.4 \sim 2.8$ 章の条件ごとの評価関数や不等式を設計変数で偏微分し, 求めた勾配すべてを用いて設計変数を更新 する. 例えば，(i) ボール飛距離の最大化は式 (24)で表され，このとき設計変数は

$$
\begin{aligned}
& \boldsymbol{\theta}_{[1]} \leftarrow \boldsymbol{\theta}_{[1]}+\frac{\partial d_{b\left[k_{o}\right]}}{\partial \boldsymbol{\theta}_{[1]}} w_{\theta} \delta_{d_{b}} \quad, \quad \dot{\boldsymbol{\theta}}_{[1]} \leftarrow \dot{\boldsymbol{\theta}}_{[1]}+\frac{\partial d_{b\left[k_{o}\right]}}{\partial \dot{\boldsymbol{\theta}}_{[1]}} w_{\dot{\theta}} \delta_{d_{b}} \\
& \ddot{\boldsymbol{\theta}}_{[j]} \leftarrow \ddot{\boldsymbol{\theta}}_{[j]}+\frac{\partial d_{b\left[k_{o}\right]}}{\partial \ddot{\boldsymbol{\theta}}_{[j]}} w_{\ddot{\theta}} \delta_{d_{b}} \quad(j=1, \cdots, n) \\
& \Delta t \leftarrow \Delta t+\frac{\partial d_{b\left[k_{o}\right]}}{\partial \Delta t} w_{\Delta t} \delta_{d_{b}} \quad, \quad \ell_{5} \leftarrow \ell_{5}+\frac{\partial d_{b\left[k_{o}\right]}}{\partial \ell_{5}} w_{\ell} \delta_{d_{b}}
\end{aligned}
$$

のように更新され， $\ell_{7}$ も $\ell_{5}$ と同様に更新する.ただし， $w_{\theta}, w_{\dot{\theta}}, w_{\ddot{\theta}}, w_{\Delta t}, w_{\ell}$ は次元の異なる設計変数ごとに設 定した重みづけであり， $\delta_{d_{b}}$ は条件 (i) の微小定数である。(i) ボール飛距離の最大化と同様に，評価関数として計 算アルゴリズムに実装される (ii) 投球後のボールと手の非接触条件と (iii) 運動開始・終了時の速度評価も設計変数 の更新に用いる。また，不等式拘束条件として実装される (iv) 自己衝突回避, (v) 角度・角速度・トルクの制限に ついては, 設計変数が条件を満足しないときのみ設計変数の更新に使用する．例えば，(iv) 自己衝突回避の条件は 式 (34) で表され, 式中 $d_{w 6[k]}$ が $d_{c}$ より小さい場合, 設計変数は

$$
\begin{aligned}
& \boldsymbol{\theta}_{[1]} \leftarrow \boldsymbol{\theta}_{[1]}+\frac{\partial d_{w 6[k]}}{\partial \boldsymbol{\theta}_{[1]}} w_{\theta} \delta_{d} \quad, \quad \dot{\boldsymbol{\theta}}_{[1]} \leftarrow \dot{\boldsymbol{\theta}}_{[1]}+\frac{\partial d_{w 6[k]}}{\partial \dot{\boldsymbol{\theta}}_{[1]}} w_{\dot{\theta}} \delta_{d} \\
& \ddot{\boldsymbol{\theta}}_{[j]} \leftarrow \ddot{\boldsymbol{\theta}}_{[j]}+\frac{\partial d_{w 6[k]}}{\partial \ddot{\boldsymbol{\theta}}_{[j]}} w_{\ddot{\theta}} \delta_{d} \quad(j=1, \cdots, n) \\
& \Delta t \leftarrow \Delta t+\frac{\partial d_{w 6[k]}}{\partial \Delta t} w_{\Delta t} \delta_{d} \quad, \quad \ell_{5} \leftarrow \ell_{5}+\frac{\partial d_{w 6[k]}}{\partial \ell_{5}} w_{\ell} \delta_{d}
\end{aligned}
$$



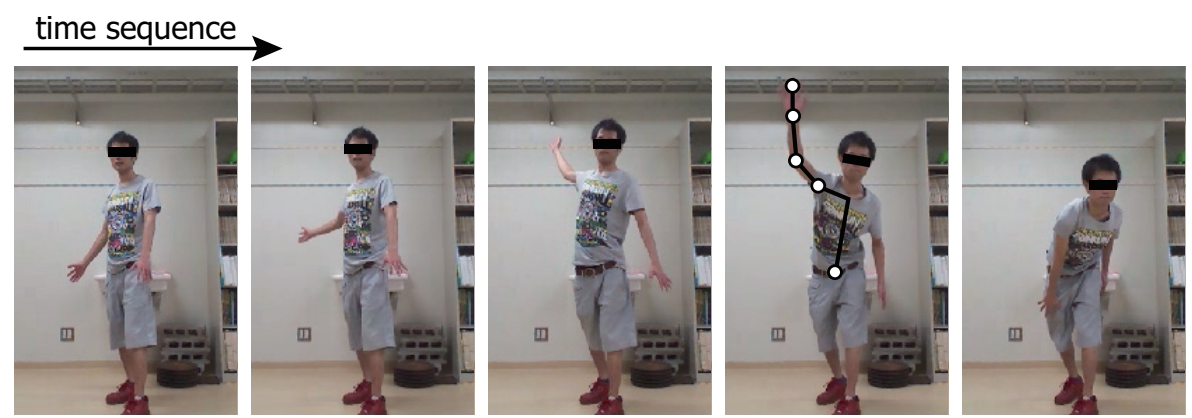

Fig. 10 Human throwing motion.

のように更新され， $\ell_{7}$ も $\ell_{5}$ と同様に更新する. ただし， $\delta_{d}$ は条件 (iv) の微小定数である. (v) 角度・角速度・トル クの制限も同様に設計変数の更新に用いる. 式 (40) と (41) 中の微小定数 $\delta$ を条件ごとに $\delta_{d_{b}}, \delta_{E_{o}}, \delta_{E_{s}}, \delta_{d}, \delta_{l i m}$ のように設定し，投球タスクの条件間の重みづけを行う.

\section{3. 計 算 結 果}

2 章の方法を用いて，投球ロボットの運動と身体の統合設計を行う. 運動の設計変数の初期值として人間の投球 運動を与える. 人間の運動は図 10 のように腕を振りかぶってボールを投げるオーバースローを採用し，己れを光 学式モーションキャプチャシステムを用いて計測した。この運動では, 図 1 の投球ロボットが再現できるように 下半身は動かさず，上半身のみを用いてボールを投げている．図 10 中，左から四つ目の図に丸マーカで示すよう に人間の骨盤，右肩，右ひじ，右手首，中指先端に代表点を設定し，これらをつないだものを人間のリンクモデ ルとする. 人間モデルと図 1 のロボットモデルはリンク長が異なるが，ともに 9 自由度の同じリンク構造をもつ. 設定した代表点の 3 次元空間位置の計測データを用いて人間モデルの関節角軌道を逆運動学解析により求め, こ

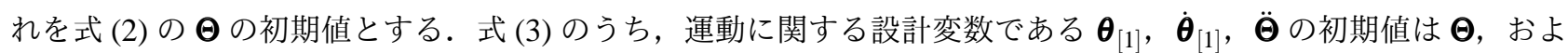
びこれをサンプリングタイム $\Delta t$ の初期值で時間差分した值を与える.このとき，運動の時系列データの点数の決 定は, 計算精度と計算時間を考慮して適切な点数を与える. 計測した人間の運動の時系列データをスプライン補間 して連続関数とし，任意のサンプリングタイムで再び離散化してデータ点数を調整した。データ点数の決定は試 行錯誤的であり，計算した時系列データを参照軌道として投球ロボットの PD 制御実験を行い，軌道に追従する運 動が実現できる必要十分な点数を与えた。ここでは, 運動の時系列データの点数は $n=119, \Delta t$ の初期值は 0.021 $\mathrm{s}$ とした．身体に関する設計変数である $\ell_{5}, \ell_{7}$ の初期值は図 1 の投球ロボット実機のリンク長を与える.これら 設計変数の初期值を 2.9 章の計算アルゴリズムを用いて更新する. 設計変数ごとの重みづけは試行錯誤的に決定 し，それぞれ $w_{\theta}=1 \times 10^{-5}, w_{\dot{\theta}}=1 \times 10^{-4}, w_{\ddot{\theta}}=1 ， w_{\Delta t}=1 \times 10^{-6}, w_{\ell}=1 \times 10^{-5}$ のように設定した。 また， 投球タスクの条件ごとの微小定数 $\delta_{d_{b}}, \delta_{E_{o}}, \delta_{E_{s}}, \delta_{d}, \delta_{\text {lim }}$ は，すべての条件で 1 とした. 投球タスクの条件の設 定は, (iv) 自己衝突回避の条件の最近傍距離 $d_{c}$ を $0.05 \mathrm{~m}$ とし, (v) 角度・角速度・トルクの制限は $2 \cdot 1$ 章で述べた

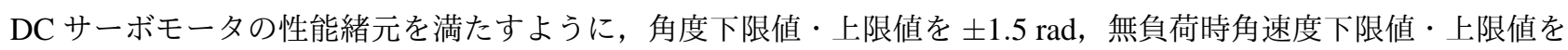
$\pm 5.5 \mathrm{rad} / \mathrm{s}$, トルク下限值・上限值を $\pm 3.0 \mathrm{Nm}$ とした。 摩擦などにより, 実機の運動でモデルよりも大きなトルク が要求されるときの対策として，モータの限界性能よりも厳しい制限を与えている.

まず，設計変数が初期值のときのロボットの投球運動の様子を図 11 に示す．黑線はロボットのリンク，丸マー 力は関節位置, 矢印は投球の方向を表す. 図 11 のロボットの運動は, 人間の投球運動の関節角軌道をそのまま口 ボットの関節に与えたものである.この運動の全時間ステップ $k=1, \cdots, 119$ でボールの飛距離 $d_{b[k]}$ を計算し, 飛 距離が最大となる時間ステップ $k_{o}$ でボールの固定を解くものとする.このため, 手を開閉させる関節 $\theta_{9}$ の軌道目 標值のみ，計算アルゴリズムとは別に，時間ステップ $k_{o}$ で立ち上がるステップ関数（またはランプ関数）を与え る. 図 12 に計算したボール飛距離 $d_{b}[k]$ を示す. 図中, 黒破線は飛距離が最大となる瞬間を表し, $k_{o}=92$ (実時 間では $1.92 \mathrm{~s}$ ） でボールを投げたときに，飛距離が最大の $1.12 \mathrm{~m}$ となった。. 以降，時間ステップ $k_{o}=92$ におけ るボール飛距離 $d_{b\left[k_{o}\right]}$ を最大化するように運動と身体を設計する. 図 13 に各関節の角度の軌道を, 図 14 に角速 度とトルクの軌道を示す。これらの図中, 青線は関節 1 , 緑線は関節 2 , 赤線は関節 3 , 水色線は関節 4 , 紫線は 関節 5, 黄色線は関節 6, 黒線は関節 7, 青破線は関節 8, 緑破線は関節 9 のデータを示し，黒破線は制限值を示 

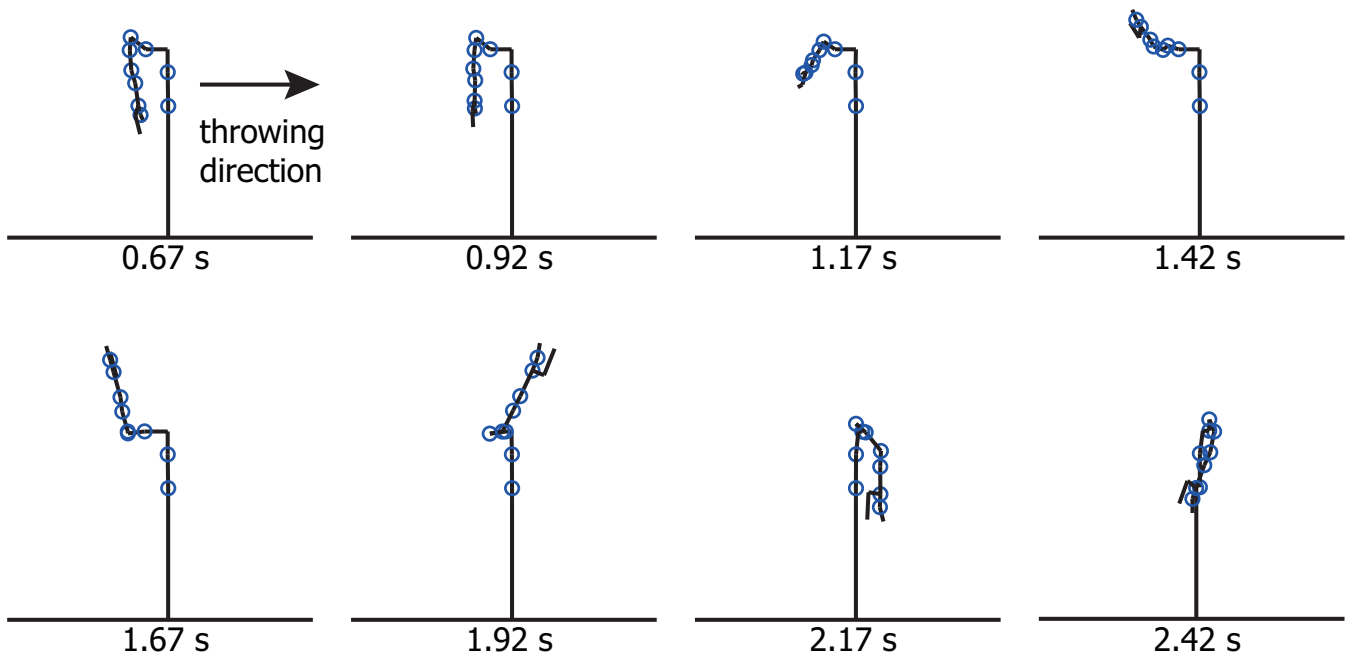

Fig. 11 Throwing motion of robot having initial body parameters and joint motion captured from human throwing motion.

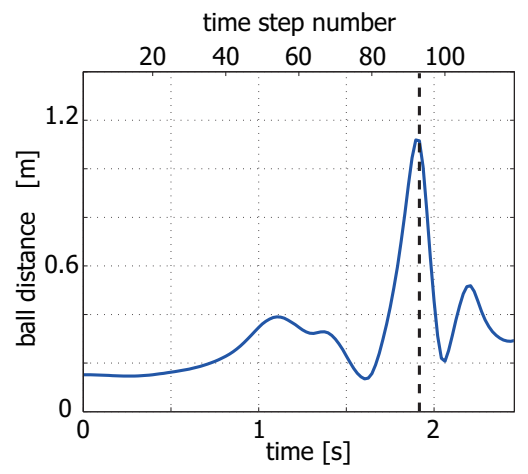

Fig. 12 Ball distance of motion in Fig.11.

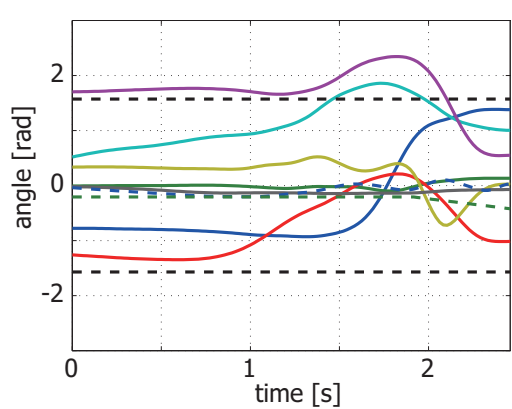

Fig. 13 Joint angle trajectories of motion in Fig.11.

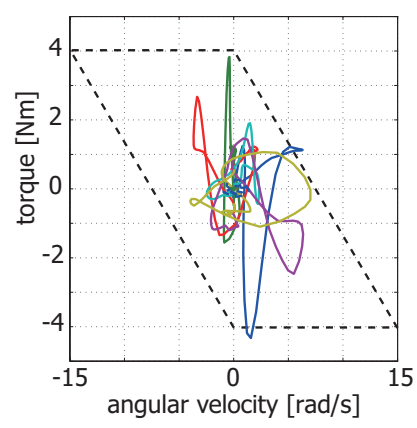

Fig. 14 Joint angular velocity and torque trajectories of motion in Fig.11.

す. 図 13 では関節 4 と 5 の軌道が制限を超え, 図 14 では関節 1 の軌道が制限を超えている.これより, 図 11 の 運動は (v) 角度・角速度・トルクの制限を満たさず，このままでは実現することはできない.

次に，身体の設計変数を初期值のまま固定し，運動に関する設計変数のみを設計した結果について述べる. 計算 終了後の投球運動の様子を図 15 に示す. 設計した運動は図 11 の運動から全時間に渡り姿勢が変化したオーバー スローの運動となった。ボール飛距離 $d_{b}\left[k_{o}\right]$ の計算履歴を図 16 に示す.ここで再帰計算の収束判定について述べ る. 計算回数が 2000 回以上のとき, 計算 1000 回ごとに直近 1000 回の計算での $d_{b}\left[k_{o}\right]$ 最大值を記録し, この值が 過去の計算で記録した $d_{b}\left[k_{o}\right]$ 最大值よりも小さくなったときに収束と判定した. 計算回数 2000 回以上としたのは, 再帰計算の初期段階では図 17 に示すように条件 (v) の満足が優先されて $d_{b}\left[k_{o}\right]$ が減少傾向にあり, ここで収束し たと判定しないためである. また, 計算 1000 回ごとに $d_{b\left[k_{o}\right]}$ の最大值を記録するのは, $d_{b\left[k_{o}\right]}$ の計算結果が振動 的になるとき, 図 16 の計算回数 100000 回以降のように長期的に見て $d_{b}\left[k_{o}\right]$ 最大值が大きくなる場合に計算を続 行するためである. 図 16 では計算 253000 回で収束と判定し，この計算には約 51 時間かかった. 条件 (i) に関し て, 図 18 にボール飛距離 $d_{b[k]}$ を示す. 運動開始時から $1.76 \mathrm{~s}$ 後にボールを投げたときに飛距離が最大の $1.49 \mathrm{~m}$ となり, 図 11 の運動から飛距離が向上した. サンプリングタイム $\Delta t$ は $0.019 \mathrm{~s}$ となり, 初期值より小さくなった ことで投球タイミングは早くなった．条件 (ii) に関して, 投球の瞬間のボール速度ベクトル $\boldsymbol{v}_{b}$ と手の向き $\boldsymbol{\ell}_{8}$ のな す角は $1.51 \mathrm{rad}$ となり, ほぼ直角である. 条件 (iii) に関して, 運動開始時の最大速度は関節 3 の $-0.140 \mathrm{rad} / \mathrm{s}$, 運 動終了時の最大速度は関節 5 の $0.669 \mathrm{rad} / \mathrm{s}$ となった. 条件 (iv) に関して, 自己衝突回避の条件に関する距離 $d_{w 6}$, $d_{w 8}, d_{t 6}, d_{t 8}$ を図 19 に示す. 図中, 青線は $d_{w 6}$, 緑線は $d_{w 8}$, 赤線は $d_{t 6}$, 水線は $d_{t 8}$ を表し, いずれも設定した 最近傍距離 $d_{c}(=0.05 \mathrm{~m})$ 以上となっている. 条件 (v)に関して, 図 20 に角度の軌道を, 図 21 に角速度とトルク の軌道を示す. 図 20 と図 21 ともに制限を満たしている. 以上より，与えた投球タスクの条件を満足するように 

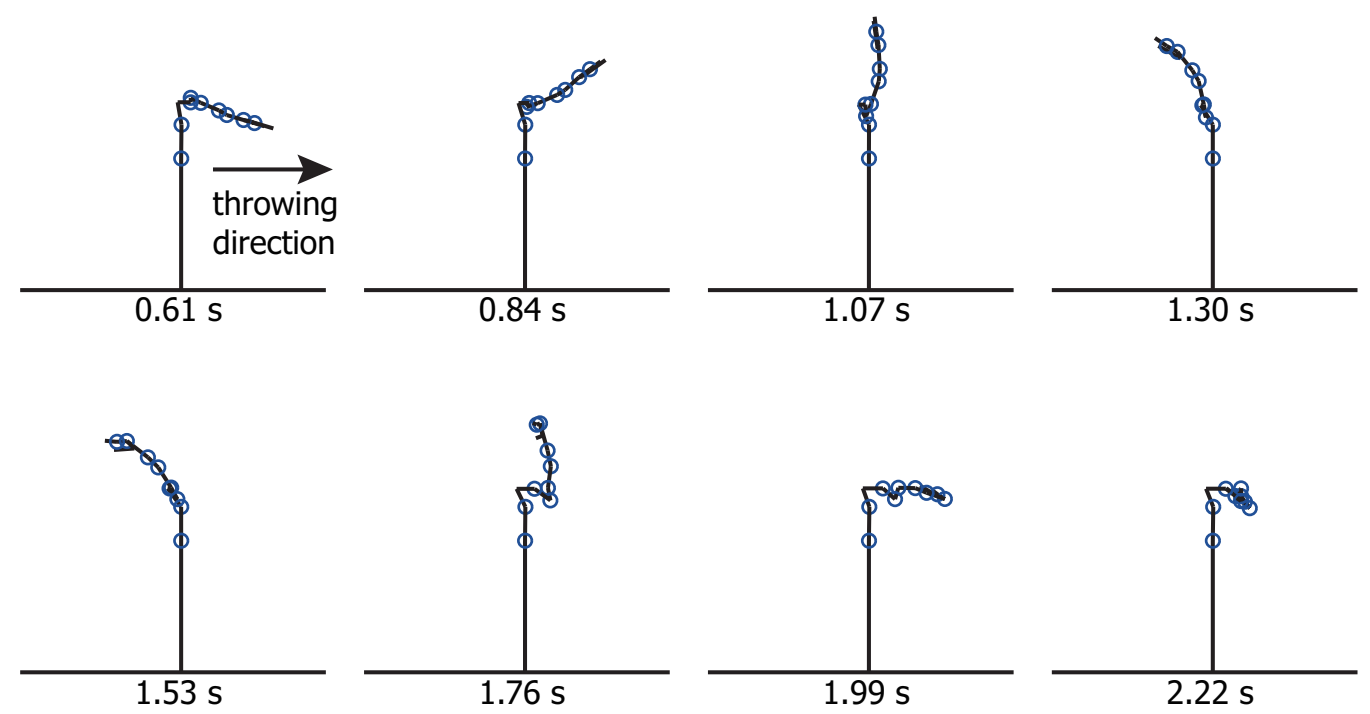

Fig. 15 Throwing motion of robot having initial body parameters and designed joint motion.

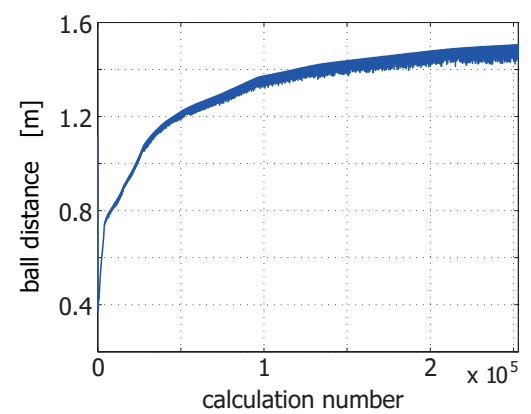

Fig. 16 Ball distance history of designed motion in Fig.15.

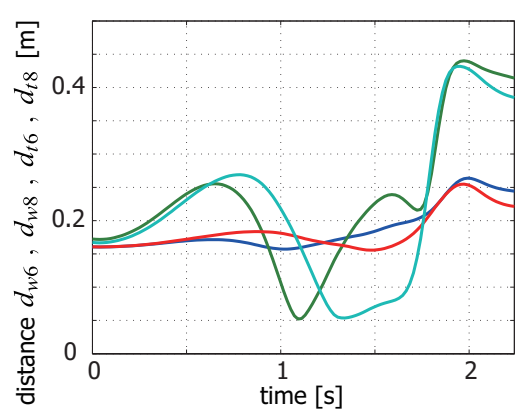

Fig. 19 Distances about condition (iv) Fig. 20 of designed motion in Fig.15.

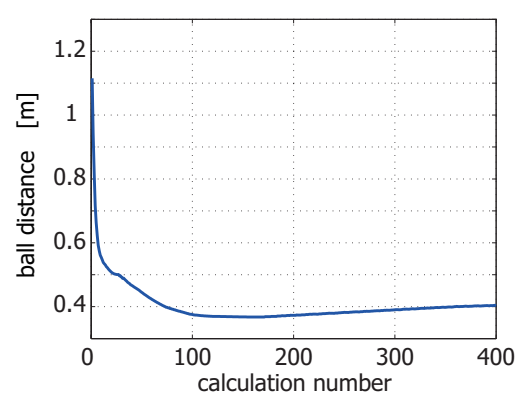

Fig. 17 Enlarged illustration of Fig. 16.

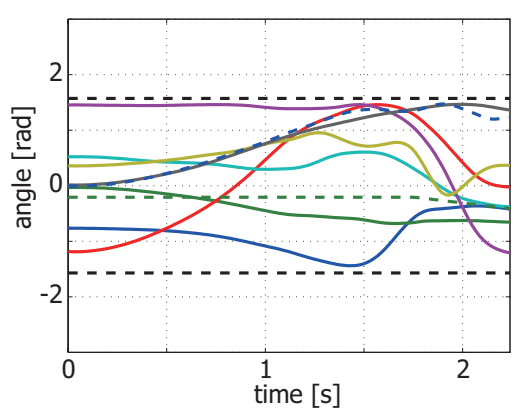

Joint angle trajectories of designed motion in Fig. 15.

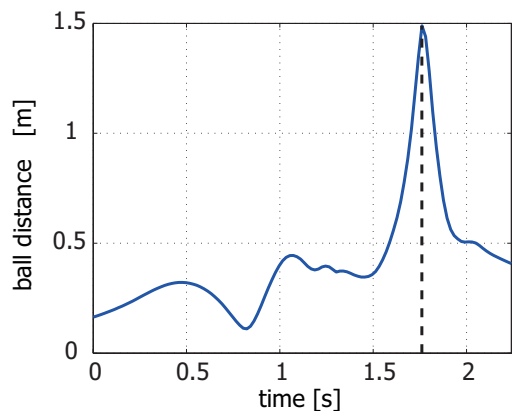

Fig. 18 Ball distance of designed motion in Fig. 15.

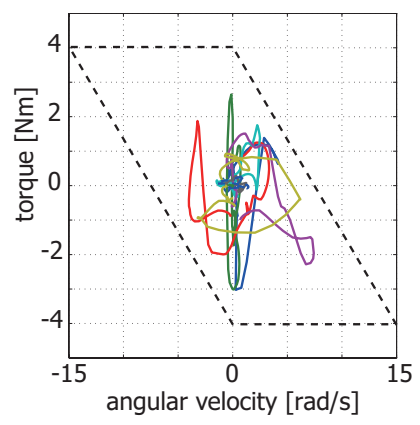

Fig. 21 Joint angular velocity and torque trajectories of designed motion in Fig.15.

\section{運動が設計された。}

さらに，運動と身体に関する設計変数すべてを設計した結果について述べる．計算終了後の投球運動の様子を 図 22 に示す. 初期身体からリンク長が変化し, 運動も図 11 や図 15 とは異なるものとなった. ボール飛距離 $d_{b}\left[k_{o}\right]$ の計算履歴を図 23 に示す. 図 23 では計算 289000 回で収束と判定し，この計算には約 60 時間かかった. 図 $24 に$ リンク長 $\ell_{5}$ と $\ell_{7}$ の計算履歴を示す. 青線は $\ell_{5}$, 緑線は $\ell_{7}$, 青破線と緑破線はそれぞれ $\ell_{5}$ と $\ell_{7}$ の最短長さを表す. 最終的に, $\ell_{5}$ と $\ell_{7}$ はともに初期身体のリンク長よりも長くなった. 計算終了時までリンク長は長くなり続ける傾 向にあるが, リンク長が長くなるほどボール飛距離の振動が大きくなり, 収束と判定された. 条件 (i) に関して, 

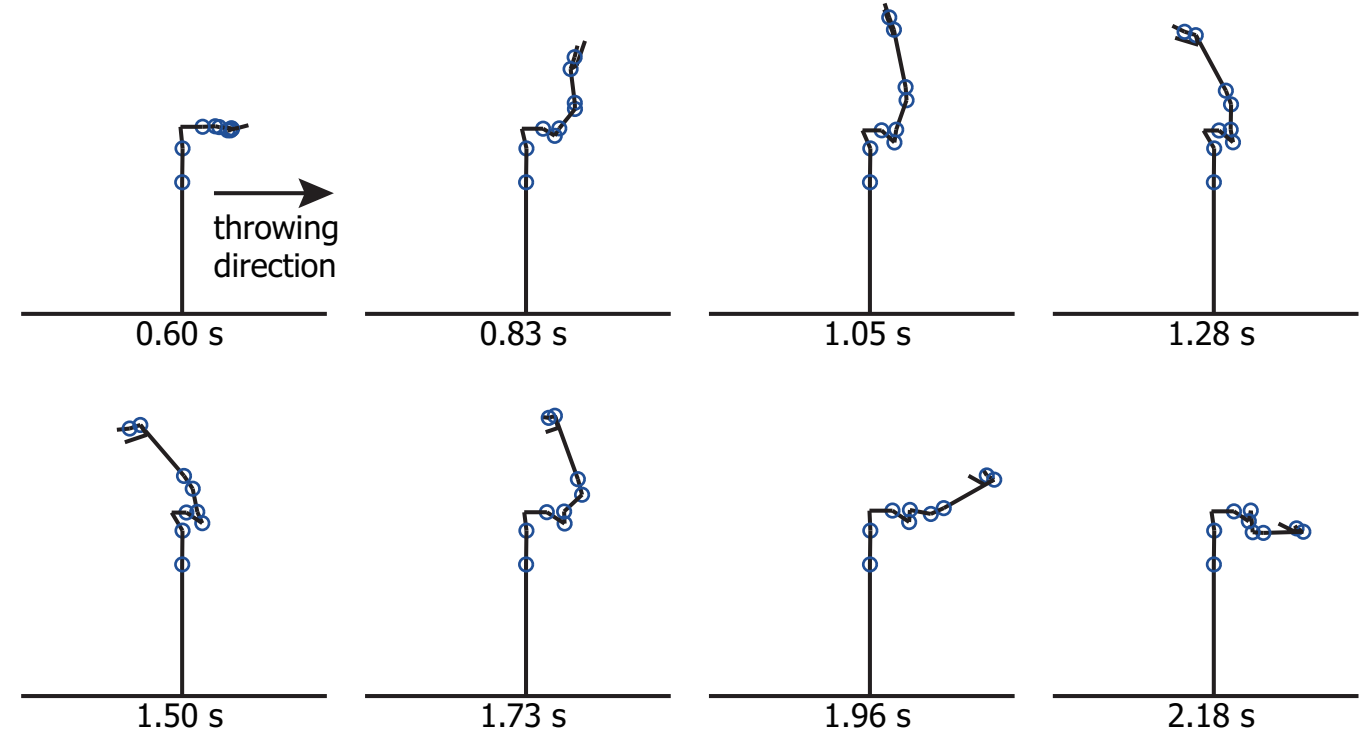

Fig. 22 Throwing motion of robot having designed body parameters and designed joint motion.

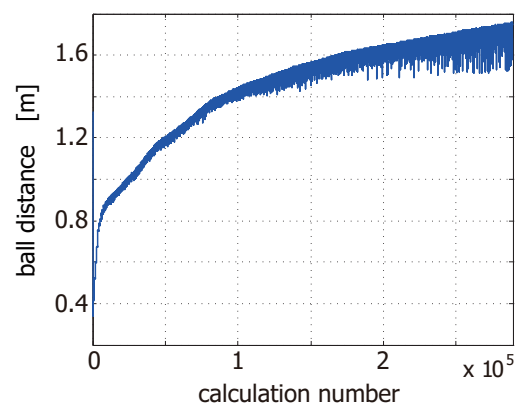

Fig. 23 Ball distance history of designed motion in Fig. 22.

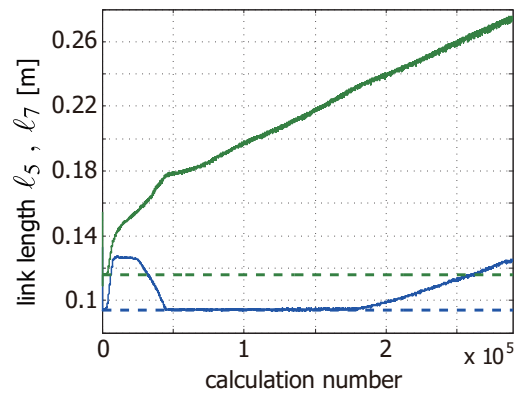

Fig. 24 Link length history of designed motion in Fig.22.

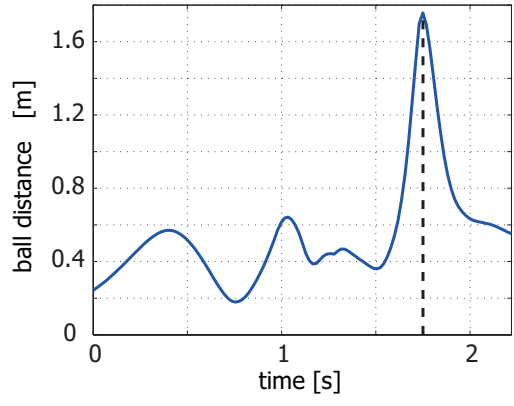

Fig. 25 Ball distance of designed motion in Fig.22.

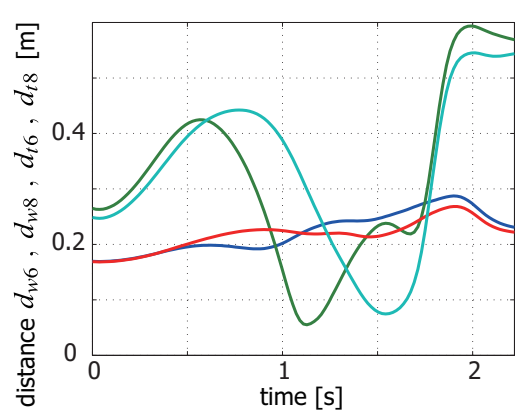

Fig. 26
Distances about condition (iv) Fig. 27 of designed motion in Fig.22.

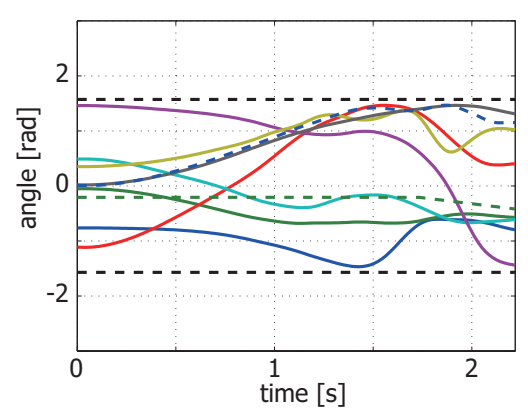

Joint angle trajectories of designed motion in Fig.22.

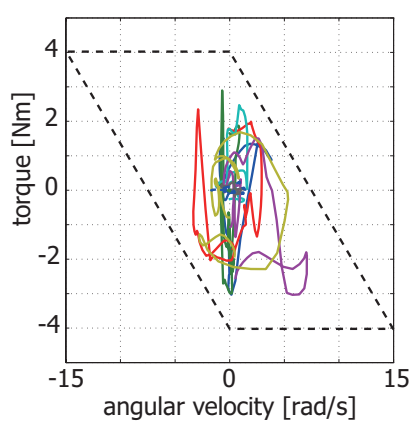

Fig. 28 Joint angular velocity and torque trajectories of designed motion in Fig.22.

図 25 にボール飛距離 $d_{b}[k]$ を示す. 運動開始時から $1.75 \mathrm{~s}$ 後にボールを投げたときに飛距離が最大の $1.76 \mathrm{~m}$ とな

り, 図 11 および図 15 の運動と比較して飛距離が向上した. サンプリングタイム $\Delta t$ は $0.019 \mathrm{~s}$ となり, 初期值よ り投球タイミングは早まった。条件 (ii) に関して, 投球の瞬間のボール速度ベクトル $v_{b}$ と手の向き $\ell_{8}$ のな角は $1.54 \mathrm{rad}$ となり，ほぼ直角である. 条件 (iii) に関して, 運動開始時の最大速度は関節 3 の $-0.196 \mathrm{rad} / \mathrm{s}$, 運動終了 時の最大速度は関節 8 の $-0.741 \mathrm{rad} / \mathrm{s}$ となった。条件 (iv) に関して, 自己衝突回避の条件に関する距離 $d_{w 6}, d_{w 8}$, $d_{t 6}, d_{t 8}$ を図 26 に示す. これらの距離はいずれも設定した最近傍距離 $d_{c}(=0.05 \mathrm{~m})$ 以上となっている. 条件 $(\mathrm{v})$ 


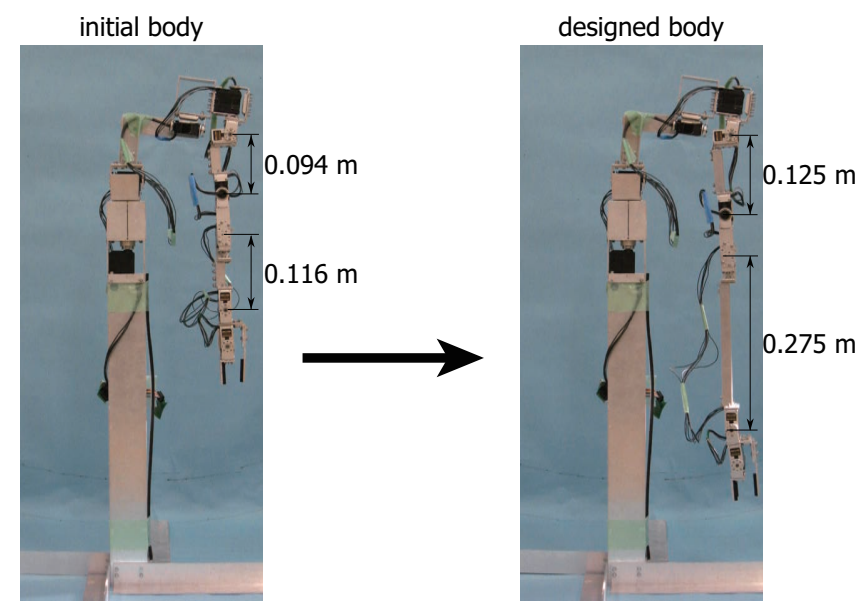

Fig. 29 Initial body and designed body.

Table 1 Flying ball distances of initial and designed body (5 trials).

\begin{tabular}{|l|r|r|r|r|r||r|}
\hline$[\mathrm{m}]$ & Trial 1 & Trial 2 & Trial 3 & Trial 4 & Trial 5 & Average \\
\hline Initial body & 1.25 & 1.50 & 1.30 & 1.25 & 1.35 & 1.33 \\
\hline Designed body & 1.75 & 1.90 & 1.90 & 1.90 & 1.90 & 1.87 \\
\hline
\end{tabular}

に関して, 図 27 に角度の軌道を, 図 28 に角速度とトルクの軌道を示す. 図 27 と図 28 ともに制限を満たしてい る. 以上より，与えた投球タスクの条件を満足するように運動が設計された.

\section{4. 実 験 結 果}

3 章で設計した運動と身体の有効性を実験により検証する．まず，初期身体と設計した身体の比較を図 $29 に$ す. 図 29 のロボット身体は, 図 24 のリンク長計算履歷の初期值および計算終了時のリンク長となるように製作し た。ボール飛距離を最大化するとき，腕部リンク長が長いほど手先速度を向上させるために有利であるのは自明 であり, 実際今回の計算結果でもリンク長 $\ell_{5}$ と $\ell_{7}$ はともに初期值よりも長くなった。 ただし, 投球運動ではアク チュエータのトルク制限を満たす必要があるため，リンク長は無制限に伸ばすことはできない。このように，投 球に適したリンク長を求める問題は，アクチュエータの制限下でボール飛距離を最大化する拘束条件付きの最適 化問題だが，運動と身体の統合設計法を用いることでこれを容易に求めることが可能である.

運動に関する設計変数のみを設計した結果である図 15 の運動を目標運動パターンとし，サンプリングタイム $0.019 \mathrm{~s}$ のゼロ次ホールドで与え, 初期身体の投球ロボットの運動を PD 制御により図 30 に示すように生成した. 図 30 の運動ではボール飛距離は $1.50 \mathrm{~m}$ となり, これは図 15 の運動のボール飛距離計算值 $1.49 \mathrm{~m}$ に近い結果と なった。

さらに，運動と身体に関する設計変数すべてを設計した結果である図 22 の運動を目標運動パターンとし，サン プリングタイム $0.019 \mathrm{~s}$ のゼロ次ホールドで与え, 設計した身体の投球ロボットの運動を PD 制御により図 31 に 示すように生成した. 図 31 の運動ではボール飛距離は $1.75 \mathrm{~m}$ となり, これは図 22 の運動のボール飛距離計算值 $1.76 \mathrm{~m}$ に近い結果となった。運動のみを設計した場合と比較して, ボールの飛距離は約 $0.25 \mathrm{~m}$ 伸びており, 運動 とともに身体を統合的に設計することで投球ロボットの投球タスクパフォーマンスを向上させることが可能であ ることが実験結果より示された。

また，実験結果に再現性があるかを確認するために，初期身体の投球運動と設計した身体の投球運動をそれぞ れ 5 回ずつ実験し, 飛距離を測定した. 実験結果を表 1 に示す. 5 回の試行の平均值は, 初期身体の運動では 1.33 $\mathrm{m}$, 設計した身体の運動では $1.87 \mathrm{~m}$ となり, 初期身体では計算值 $1.49 \mathrm{~m}$ よりも短く, 設計した身体では計算值 $1.76 \mathrm{~m}$ よりも長い結果となった。実験結果が計算結果からずれる原因として, 部品のガタおよび弾性変形, 各関 節のモータバックラッシュや摩擦，PD 制御の軌道追従誤差などが考えられる。このうち, PD 制御の軌道追従誤 差について, 図 32 を用いて述べる. 図 32 は, 初期身体の 4 回目の実験結果であり, 図中, 青実線は実際の関節 


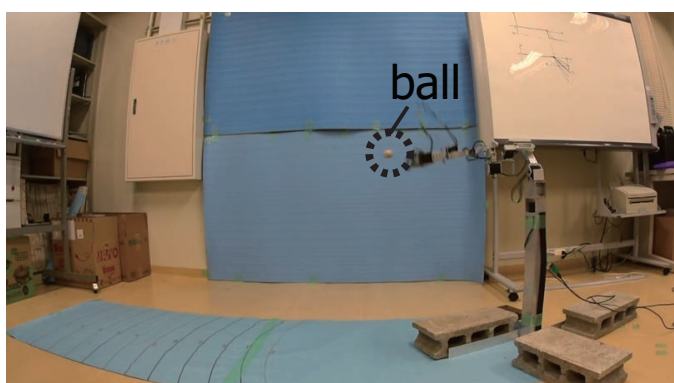

$1.99 \mathrm{~s}$

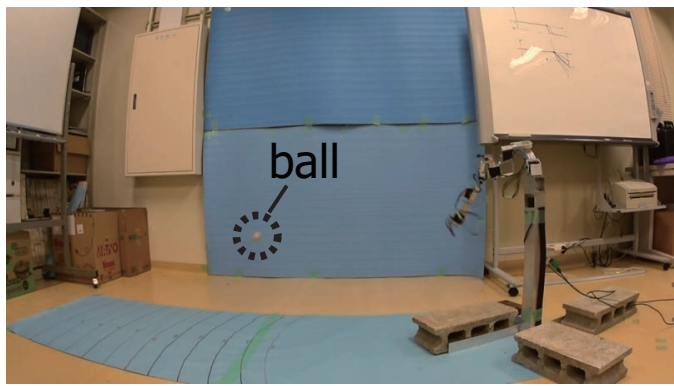

$2.22 \mathrm{~s}$

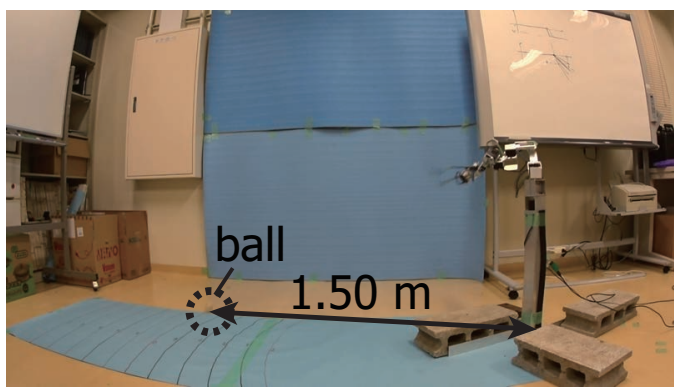

$2.33 \mathrm{~s}$

Fig. 30 Experimental validation of initial body and designed motion in Fig.15.

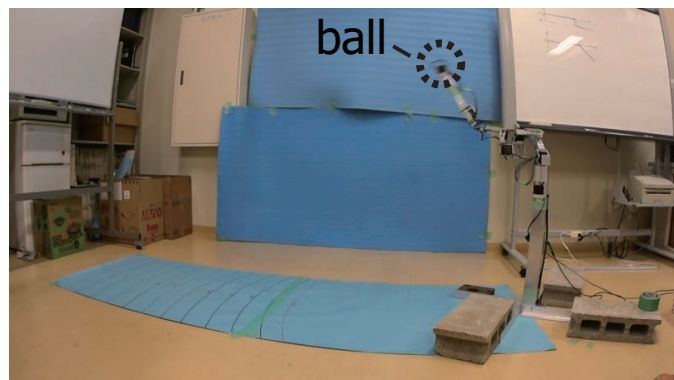

$1.96 \mathrm{~s}$

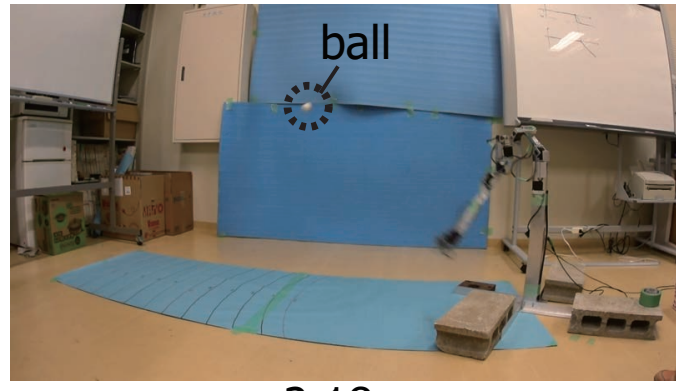

$2.18 \mathrm{~s}$

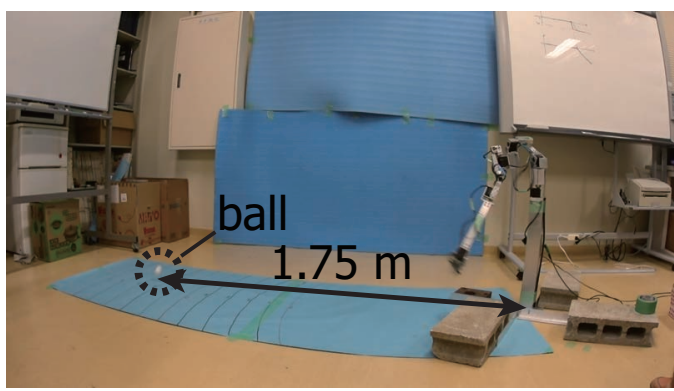

$2.43 \mathrm{~s}$

Fig. 31 Experimental validation of designed body and designed motion in Fig. 22.

角度の軌道，青破線は目標運動パターン，黒破線は目標運動パターンの投球タイミングを表す。ハンドの開閉に 用いる関節 9 の軌道は, 投球タイミングで立ち上がるステップ関数またはランプ関数で与えている. 投球タイミ ングの前後では一部の関節角度軌道が大きく変化しており, PD 制御の軌道追従誤差, 主に位相遅れが大きくなる 傾向がある．軌道追従誤差を含む実際の関節角度軌道とロボットモデルを用いてボールの飛距離を計算した結果 を図 33 に示す。図 33 左は初期身体の 4 回目の実験結果，右は設計した身体の 5 回目の実験結果であり，それぞ れの図中，青実線は実際の関節角度軌道を用いたボール飛距離，青破線は目標運動パターンを用いたボール飛距 離，黒破線は目標運動パターンの投球タイミングを表す. 図 32 で実際の関節角度軌道が目標運動パターンに対し て遅れているように，図 33 ではボール飛距離のピークに遅れが生じている．初期身体の実験でボール飛距離が短 くなる主な原因として，実際にボール飛距離が最大となる瞬間に投球が行えていないことが考えられる. 投球タ イミングを調整するためには，関節 9 の軌道（ステップ関数またはランプ関数）の立ち上がりタイミングや立ち 上がり量などを調整する。一方, 設計した身体の運動では, 実際のボール飛距離が目標運動パターンの計算值よ りも長くなった。この現象の原因について考察する。目標運動パターンはモータの限界性能に対して余裕を持っ た制限を満たすように設計されているのに対し，ロボット実機の運動ではモータの限界性能まで動作してしまう. そのため, 軌道追従制御の最中に実際の手先速度が瞬間的に目標運動パターンの手先速度を超えることがあり得 る.この誤差を減らす対策として，目標運動パターンの設計でモータの限界性能を制限として与えることが考え られるが，この場合摩擦などの外乱の影響によりロボット実機では実現できない目標運動パターンが設計される リスクもあり，注意が必要である. 

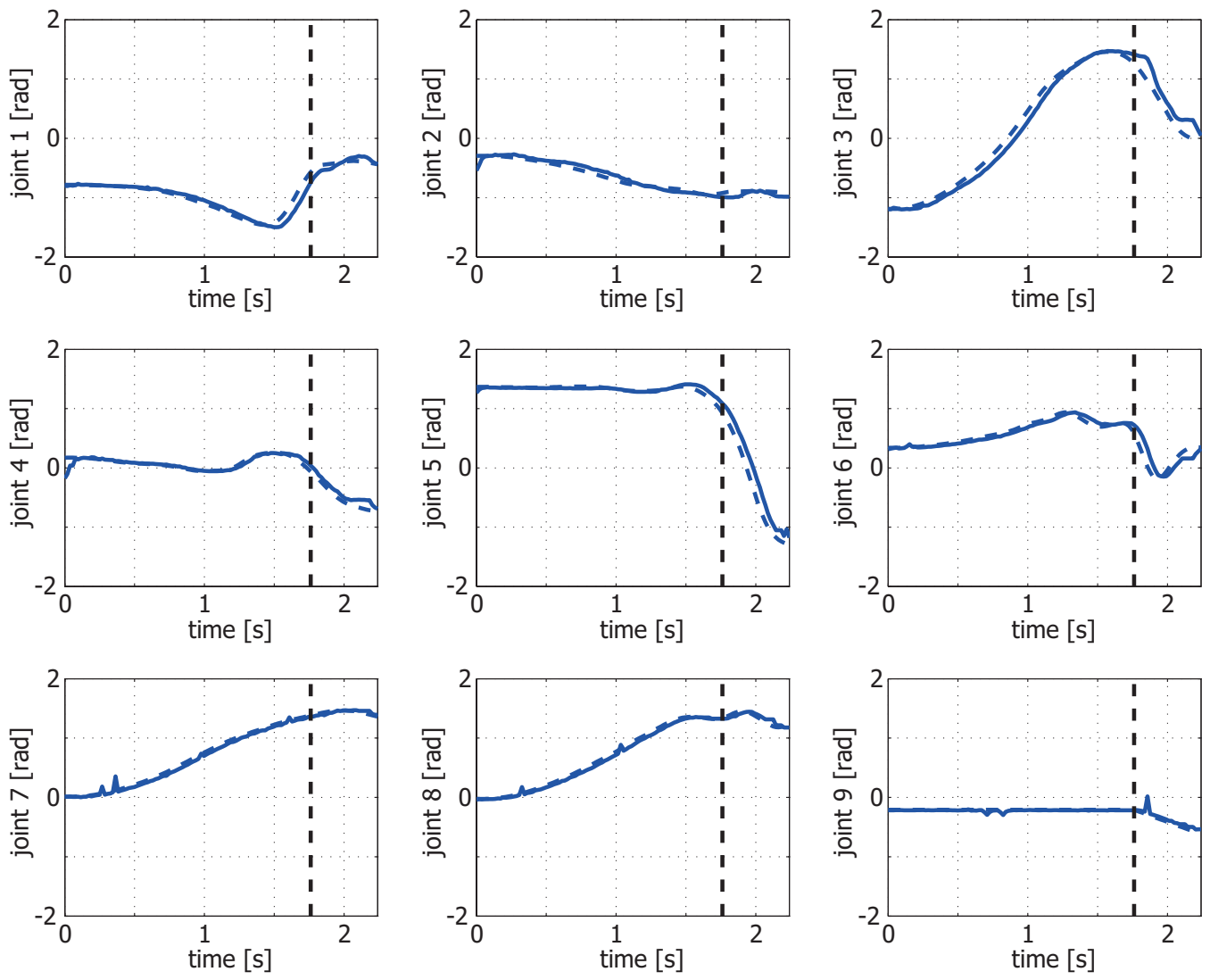

Fig. 32 Joint angle trajectories (trial 4 of initial body).
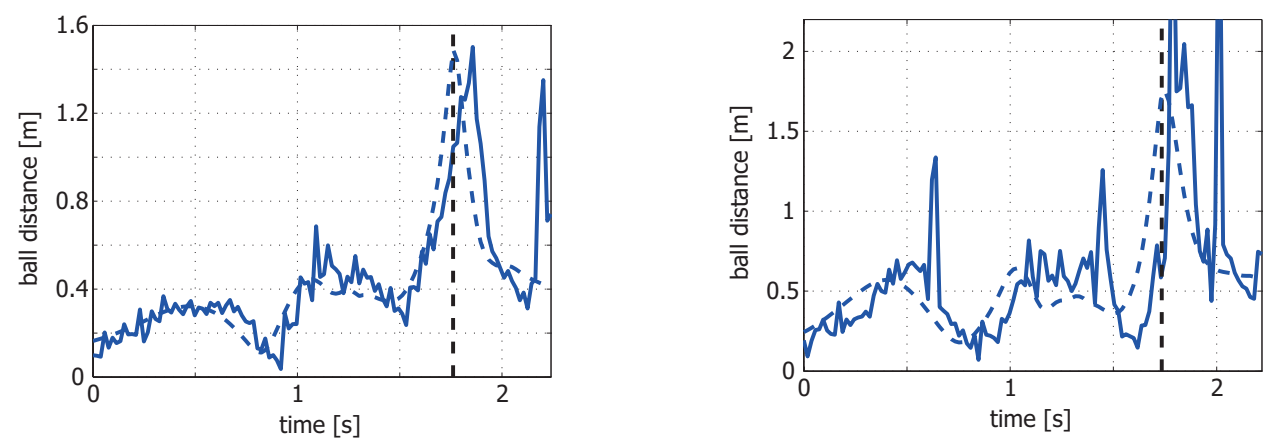

Fig. 33 Flying ball distances of output and reference data (left : initial body, right : designed body).

\section{5. お り に}

本論文では，ロボットの目的のタスクのパフォーマンスを高めるために，一つの計算アルゴリズムの枠組みの 中でロボットの運動と身体を統合的に設計する事例として，9自由度空間マニピュレータである投球ロボットの投 球タスクと，これに適したロボットの身体を統合的に設計する事例について報告した。主な結果を以下に示す.

1. ロボットの運動の時系列データと身体パラメータを設計変数とし，これらを計算アルゴリズムの中で同時に 求める方法を提案した。本論文の提案する運動と身体の統合設計では，運動とともに身体も設計することで， ロボットは目的の運動を実現するために有利な身体を獲得する.

2. 投球ロボットを検証例として，人間のオーバースローから投球ロボットの運動と身体を設計した。投球タス クの条件として，(i) ボール飛距離の最大化，(ii) 投球後のボールと手の非接触条件，(iii) 運動開始・終了時の 速度評価，(iv) 自己衝突回避の条件，（v) 角度・角速度・トルクの制限を与えた。身体を不変として運動のみ を設計した場合と，運動と身体を設計した場合の計算結果を得て，これらは投球タスクの条件を満たすこと を確認した。計算結果では，運動のみを設計した場合のボール飛距離は $1.49 \mathrm{~m} ，$ 運動と身体を設計した場合 
のボール飛距離は $1.76 \mathrm{~m}$ となった.

3. 計算結果の有効性を実験により検証した。実験では計算結果の運動を目標運動パターンとして与え，PD制御 によりロボット実機の運動を生成した。また，初期身体用と設計後の身体用にリンク長の異なる二種類の腕部 を製作し，それぞれの実験で用いた。運動のみを設計した場合と，運動と身体を設計した場合とでそれぞれ 5 回ずつ実験を行い, 運動のみを設計した場合のボール飛距離は平均 $1.33 \mathrm{~m}$, 運動と身体を設計した場合の ボール飛距離は平均 $1.87 \mathrm{~m}$ となった. 運動と身体を設計した場合の方が運動のみを設計した場合よりもボー ル飛距離が伸び，運動とともに身体を統合的に設計することで投球ロボットの投球タスクパフォーマンスを 向上させることが可能であることが実験結果より示された.

\section{文献}

Braun, D. J., Petit, F., Huber, F., Haddadin, S., Smagt, P. v. d., Albu - Schäffer, A. and Vijayakumar, S., Robots driven by compliant actuators: optimal control under actuation constraints, IEEE Transactions on Robotics, Vol.29, No.5 (2013), pp.1085-1101.

Endo, K., Maeno, T. and Kitano, H., Co-evolution of morphology and walking pattern of biped humanoid robot using evolutionary computation -designing the real robot-, Proceedings of the 2003 IEEE International Conference on Robotics and Automation (ICRA) (2003a), pp.1362-1367.

Endo, K., Maeno, T. and Kitano, H., Co-evolution of morphology and walking pattern of biped humanoid robot using evolutionary computation - evolutionary designing method and its evaluation-, Proceedings of the 2003 IEEE/RSJ International Conference on Intelligent Robots and Systems (IROS) (2003b), pp.340-345.

Kanoun, O., Lamiraux, F., Wieber, P. B., Kanehiro, F., Yoshida, E. and Laumond, J. P., Prioritizing linear equality and inequality systems: application to local motion planning for redundant robots, Proceedings of the 2009 IEEE International Conference on Robotics and Automation (ICRA) (2009), pp.724-729.

Kawai, Y., Park, J., Horii, T., Oshima, Y., Tanaka, K., Mori, H., Nagai, Y., Takuma, T. and Asada, M., Throwing skill optimization through synchronization and desynchronization of degree of freedom, RoboCup 2012: Robot Soccer World Cup XVI (2012), pp.178-189.

萱島駿, 岡田昌史, 身体パラメータに合わせた胸骨圧迫の運動最適化, 第 18 回ロボティクスシンポジア (2013), $1 \mathrm{~A} 3$. 宮部哲郎, 岡田昌史, 力学的整合性を満たす歩行ロボットの加速度運動パターン設計, 第 19 回ロボティクスシンポ ジア (2014), 1 B1.

中岡慎一郎, 中澤篤志, 金広文男, 金子健二, 森澤光晴, 比留川博久, 池内克史, 脚タスクモデルを用いた 2 足歩行ヒュー マノイドロボットによる人の舞踊動作の再現, 日本ロボット学会誌, Vol.24, No.3 (2006), pp.388-399.

Nakaoka, S., Kajita, S. and Yokoi, K., Intuitive and flexible user interface for creating whole body motions of biped humanoid robots, Proceedings of the 2010 IEEE/RSJ International Conference on Intelligent Robots and Systems (IROS) (2010), pp.1675-1682.

岡田昌史, Pekarovskiy, A. and Buss, M., モデル化誤差に関する感度解析に基づいた投擲のロバスト運動設計, 第 32 回日本ロボット学会学術講演会 (2014), 1Q2-05.

Suleiman, W., Yoshida, E., Kanehiro, F., Laumond, J., P. and Monin, A., On human motion imitation by humanoid robot, Proceedings of the 2008 IEEE International Conference on Robotics and Automation (ICRA) (2008), pp.2697-2704.

Yamane, K. and Nakamura, Y., Dynamics filter - concept and implementation of on-line motion generator for human figures, IEEE Transactions on Robotics and Automation, Vol.19, No.3 (2003), pp.421-432.

Yamane, K. and Hodgins, J., Simultaneous tracking and balancing of humanoid robots for imitating human motion capture data, Proceedings of the 2009 IEEE/RSJ International Conference on Intelligent Robots and Systems (IROS) (2009), pp.2510-2517.

\section{References}

Braun, D. J., Petit, F., Huber, F., Haddadin, S., Smagt, P. v. d., Albu - Schäffer, A. and Vijayakumar, S., Robots driven by compliant actuators: optimal control under actuation constraints, IEEE Transactions on Robotics, Vol.29, No.5 
(2013), pp.1085-1101.

Endo, K., Maeno, T. and Kitano, H., Co-evolution of morphology and walking pattern of biped humanoid robot using evolutionary computation -designing the real robot-, Proceedings of the 2003 IEEE International Conference on Robotics and Automation (ICRA) (2003a), pp.1362-1367.

Endo, K., Maeno, T. and Kitano, H., Co-evolution of morphology and walking pattern of biped humanoid robot using evolutionary computation - evolutionary designing method and its evaluation-, Proceedings of the 2003 IEEE/RSJ International Conference on Intelligent Robots and Systems (IROS) (2003b), pp.340-345.

Kanoun, O., Lamiraux, F., Wieber, P. B., Kanehiro, F., Yoshida, E. and Laumond, J. P., Prioritizing linear equality and inequality systems: application to local motion planning for redundant robots, Proceedings of the 2009 IEEE International Conference on Robotics and Automation (ICRA) (2009), pp.724-729.

Kawai, Y., Park, J., Horii, T., Oshima, Y., Tanaka, K., Mori, H., Nagai, Y., Takuma, T. and Asada, M., Throwing skill optimization through synchronization and desynchronization of degree of freedom, RoboCup 2012: Robot Soccer World Cup XVI (2012), pp.178-189.

Kayashima, S. and Okada, M., Motion optimization for first aid chest compression consistent with body parameter, Proceedings of the 18th Robotics Symposia (2013), 1A3 (in Japanese).

Miyazaki, T. and Okada, M., Acceleration pattern design of walking robot satisfying dynamical consistency, Proceedings of the 19th Robotics Symposia (2014), 1B1 (in Japanese).

Nakaoka, S., Nakazawa, A., Kanehiro, F., Kaneko, K., Morisawa, M., Hirukawa, H. and Ikeuchi, K., Leg task models for reproducing human dance motions on biped humanoid robots, Journal of the Robotics Society of Japan, Vol.24, No.3 (2006), pp.388-399 (in Japanese).

Nakaoka, S., Kajita, S. and Yokoi, K., Intuitive and flexible user interface for creating whole body motions of biped humanoid robots, Proceedings of the 2010 IEEE/RSJ International Conference on Intelligent Robots and Systems (IROS) (2010), pp.1675-1682.

Okada, M., Pekarovskiy, A. and Buss, M., Model-ka gosa ni kansuru kando kaiseki ni motozuita touteki no robust undou sekkei, Proceedings of the 32nd Annual Conference of the Robotics Society of Japan (2014), 1Q2-05 (in Japanese).

Suleiman, W., Yoshida, E., Kanehiro, F., Laumond, J., P. and Monin, A., On human motion imitation by humanoid robot, Proceedings of the 2008 IEEE International Conference on Robotics and Automation (ICRA) (2008), pp.2697-2704.

Yamane, K. and Nakamura, Y., Dynamics filter - concept and implementation of on-line motion generator for human figures, IEEE Transactions on Robotics and Automation, Vol.19, No.3 (2003), pp.421-432.

Yamane, K. and Hodgins, J., Simultaneous tracking and balancing of humanoid robots for imitating human motion capture data, Proceedings of the 2009 IEEE/RSJ International Conference on Intelligent Robots and Systems (IROS) (2009), pp. $2510-2517$. 